\title{
A CRYPT WITH THIRD-CENTURY COINS IN THE CEMETERY OF OPUSHKI ${ }^{1}$
}

\author{
Igor N. Khrapunov \\ V.I. Vernadsky Crimean Federal University, Simferopol, Russian Federation
}

\begin{abstract}
The cemetery of Opushki is located about $15 \mathrm{~km}$ east of Simferopol, in the Crimean foothills. In the process of excavations, carried out since 2003, a variety of funerary constructions belonging to different archaeological cultures have been discovered. The crypt researched in the current article contained four burials, which were especially interesting because of the find of six coins inside of them. The excavation above the burial chamber of this vault discovered a childs burial accompanied with varied grave goods, similarly to those made in the crypt. The burials discussed in the present study were made in the second half of the third century AD. The second half of the $3^{\text {rd }}$ century AD was the period represented in Crimea by the smallest number of complexes in comparison with the previous and the following periods. Varied grave goods from the crypt and the childs grave greatly expand our notion of the material culture of those people who inhabited the Crimean foothills in that half of the century, which is difficult to be discovered by archaeological methods. Furthermore, the crypt No. 133 belongs to a big group of grave constructions which were widely spread in Crimea in the Late Roman period. Their distinctive feature is a short dromos. Initially, the latter crypts appeared in the first half of the $3^{\text {rd }}$ century AD. However, several of them as well belong to the second half of the $3^{\text {rd }}$ century $\mathrm{AD}$. In the fourth century AD, the majority of burials were made in such crypts close to the Crimean foothills. Many researchers interpret specific construction of these crypts as an evidence of the penetration into Crimea of the forefathers of mediaeval North Caucasian Alans. The material culture of the population of the Crimean foothills in the Late Roman period could be interpreted as eclectic, developed under the influence from various factors. Its sources were ancient and the Sarmatian cultures. Besides, the research showed that there were found some local hand-made vessels, analogies of which were never found outside of the peninsula. Some of the artefacts had penetrated to Crimea area from the areas populated by Germanic tribes.
\end{abstract}

Key words: Crimea, Roman period, cemeteries, funeral rites, grave goods, Sarmatians, Alans, Germans, intercultural connections.

Citation. Khrapunov I.N., 2020. Sklep s monetami III v. n.e. iz mogil'nika Opushki [ACrypt with Third-Century Coins in the Cemetery of Opushki]. Nizhnevolzhskiy Arkheologicheskiy Vestnik [The Lower Volga Archaeological Bulletin], vol. 19, no. 2, pp. 247-278. DOI: https://doi.org/10.15688/nav.jvolsu.2020.2.13

УДК 903'1(47+57):726.823

Дата поступления статьи: 01.11.2020

ББК $63.442(2)-427$

Дата принятия статьи: 24.11.2020

\section{СКЛЕП С МОНЕТАМИ ІІ в. Н.э. ИЗ МОГИЛЬНИКА ОПУШКИ ${ }^{1}$}

\author{
Игорь Николаевич Храпунов \\ Крымский федеральный университет им. В.И. Вернадского, г. Симферополь, Российская Федерация
}

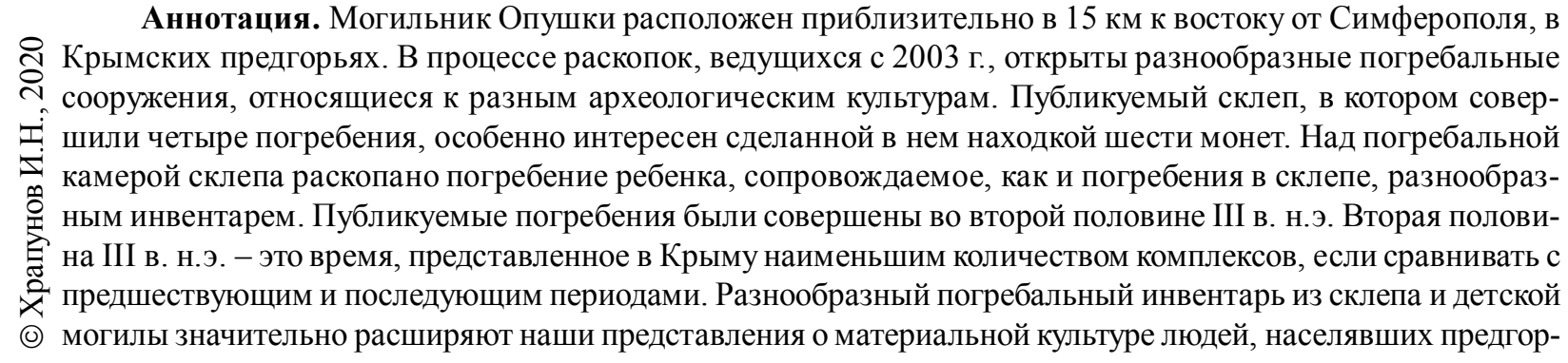


ный Крым в этой трудноуловимой археологическими методами половине столетия. Склеп № 133 принадлежит большой группе погребальных сооружений, распространенных в Крыму в позднеримское время. Их отличительной чертой является короткий дромос. Первые склепы такой конструкции появились в первой половине III в. н.э. Ко второй половине III в. н.э. тоже относятся немногие из них. В IV в. н. э. в таких склепах в крымских предгорьях производилось большинство захоронений. Многие исследователи видят в конструкции склепов свидетельство проникновения в Крым предков средневековых северокавказских алан. Материальную культуру населения крымских предгорий позднеримского времени можно назвать эклектичной, сложившейся под воздействием разных факторов. Ее источниками служили античная и сарматская культуры. На месте были произведены не имеющие аналогий за пределами полуострова лепные сосуды. Некоторые вещи попали в Крым с территорий, заселенных германцами.

Ключевые слова: Крым, римское время, могильники, погребальные обряды, погребальный инвентарь, сарматы, аланы, германцы, межкультурные контакты.

Цитирование. Храпунов И. Н., 2020. Склеп с монетами III в. н.э. из могильника Опушки // Нижневолжский археологический вестник. Т. 19, № 2. С. 247-278. DOI: https://doi.org/10.15688/nav.jvolsu.2020.2.13

Могильник Опушки расположен приблизительно в 15 км к востоку от Симферополя, в Крымских предгорьях. В процессе раскопок, ведущихся с 2003 г., открыты разнообразные погребальные сооружения, относящиеся к разным археологическим культурам. В том числе и склепы описанного ниже типа. Они находятся в центре дискуссий об этнических процессах, происходивших в Крыму в III-IV вв. н.э. Публикуемый склеп особенно интересен сделанной в нем находкой шести монет, что позволяет уточнить давно обсуждаемую хронологию подобных погребальных сооружений.

Описание погребального сооружения. Могила № 133. Склеп (рис. 1, 2, 5). Прямоугольная в плане входная яма ориентирована с запада на восток. Ее размеры 2,2 × 1,0 м, глубина в материке 1,6 м, от современной дневной поверхности - 3,05 м. В торцевой, западной стене входной ямы на высоте 0,65 м от дна сделана ступенька шириной 0,2 м. Дно входной ямы незначительно понижалось к входу в дромос. У северной стены входной ямы, в ее заполнении, на высоте 0,2 м находился лепной сосуд (рис. 6,1). Кроме того, в заполнении входной ямы обнаружены фрагменты амфор, гончарных, краснолаковых и лепных сосудов. Дромос сделан в восточной стене входной ямы. Вход в него был закрыт двумя крупными плитами. В щели между плитами и стенами входной ямы заложили небольшие камни. Размеры дромоса составляли $0,9 \times 0,9$ м.

Погребальная камера прямоугольная в плане. Ее размеры 3,2 × 2,7 м. Длинная ось погребальной камеры перпендикулярна длинной оси входной ямы. Пол погребальной камеры расположен на 0,3 м ниже пола дромоса. Переход оформлен в виде ступеньки. Погребальная камера заполнена рухнувшим сводом.

В погребальной камере обнаружены погребения четырех людей. Все они похоронены в конструкциях, которые можно условно назвать гробами. Сохранился тлен от стенок на высоту $0,05-0,1$ м. Все погребения ориентированы головами на запад, то есть к входу в погребальную камеру.

Погребение I совершено у северной стены погребальной камеры (рис. 3,I). Размеры гроба составляли $1,9 \times 0,4$ м. Сохранились кости черепа, плечевые, тазовые, ребра, длинные кости ног. Кости стоп и пальцев на ногах, а также некоторые ребра перемещены. Тазовые кости покрыты слоем черного органического тлена. От позвоночника сохранился костный тлен. Судя по положению сохранившихся костей, погребение было совершено в вытянутом положении на спине. Череп повернут лицевой стороной влево. Ноги, вероятно, были согнуты в коленях и завалились влево. У южной стенки внутри гроба лежал камень. У правой плечевой кости найдены бронзовая пряжка (рис. 8,9) и серебряное кольцо с зажимом (рис. 8,8). Еще три серебряные пряжки лежали на тазовых костях (рис. 8,1,2,4, 14,1). Железный предмет находился на месте живота (распался). Слева от тазовых костей обнаружены серебряные накладка и фрагмент наконечника ремня (рис. 10,8). Под левой бедренной костью зачищены остатки железного стержневидного предмета (распался). У северной стенки гроба лежал костяной гребень (рис. 10,11, 14,5). В ногах найдена серебряная обойма (рис. 8,16 ). 
Гроб с погребением II располагался вплотную к гробу с погребением I с юга (рис. 3,II). Ширина гроба 0,55 м. Его длину измерить нельзя, так как восточная стенка не сохранилась. В юго-западном углу гроба справа от черепа лежал камень. Сохранились кости черепа, позвоночник, ребра, тазовые кости, длинные кости рук и ног, а также ступни. Погребение совершено в вытянутом положении на спине.

На месте правого плеча расчищены оселок (рис. 9,13) и нож (рис. 11,5). На северной стенке гроба лежали кость животного и нож (рис. 11,4). У левой плечевой кости расчищены бусина (рис. 12,3) и фрагменты, вероятно, от трех железных ведерковидных подвесок (рис. 12,4) (от одной подвески сохранился только обломок нижней части).

Слева от таза находились два серебряных наконечника ремня (рис. 10,6,7) и подвеска от еще одного наконечника (рис. 10,1, 13,8), справа от правой бедренной кости - две серебряные пряжки (рис. 8,3,15, 14,2), в ногах слева - нож (рис. 11,2) и две железные пряжки (рис. 9,1,5). Справа от стоп, под стенкой гроба лежал камень. В головах погребенного за гробом находились кость животного и нож (рис. 11,7).

Гроб с погребением III находился вплотную к гробу с погребением II с юга (рис. 4,III). Ширина гроба составляла 0,5 м, его длину измерить невозможно, так как восточная стенка не сохранилась. От погребенного остались смещенные обломки черепа и ребер, а также тазовые кости, кости рук и ног. Погребение совершено в вытянутом положении на спине. Под южную стенку гроба был положен камень. За гробом, в головах находились кость животного, нож (рис. 11,6) и два лепных сосуда (рис. $10,10,12,1$ ), рядом расчищена яичная скорлупа, а также след от сгоревшего деревянного предмета. Скопление предметов обнаружено на левой бедренной кости, в том числе кремневый отщеп (рис. 12,21), серебряная (рис. 8,14 ) и бронзовая (рис. 8,12 ) пряжки и железный стержневидный предмет (рис. 9,12). На правом колене лежал топор (рис. 11,1 ), под ним бронзовое кольцо с зажимом (рис. 8,11$)$ и рядом с ним серебряное кольцо с зажимом (рис. 8,13). Справа от правых берцовых костей находился нож (рис. 11,3), слева от левых берцовых костей - кремневый отщеп (рис. 12,14), железная пряжка (рис. 9,3) и мелкие обломки бронзового предмета, в ногах - железная пряжка (рис. 9,4).

Гроб с погребением IV располагался на 0,4 м южнее гроба с погребением III (рис. 4,IV). Размеры гроба составляли $1,9 \times 0,35$ м. От погребенного сохранились перемещенные кости черепа, обломки таза, два ребра, длинные кости рук и ног. Погребение совершили в вытянутом положении на спине. На месте груди обнаружена железная фибула (рис. 10,9).

В ногах на слое органического тлена черного цвета расчищены железный стержневидный предмет с остатками деревянной рукояти (рис. 9,14), железные пряжки (рис. 9,2,8), кремневый отщеп (рис. 12,25), точильный камень (рис. 9,10), многочисленные бусы (рис. 12,5-13,15-20,22-24,26-34,14,7). Бусы лежали компактно, но не как обычно на костях ног, а в стороне в северо-восточном углу гроба. Среди перечисленных предметов расчищены лежавшие «стопкой» (рис. 13,7) шесть монет: по одной Юлии Домны (рис. 13,1), Филиппа I Араба (рис. 13,3), Траяна Деция (рис. 13,6) и три Гордиана III (рис. 13,2,4,5).

Пространство вдоль южной стены погребальной камеры занимали кости лошади. Череп находился в юго-западном углу. Сохранились кости от всего скелета. Создается впечатление, что вдоль стены погребальной камеры сложили куски изрубленной туши в относительном анатомическом порядке. На черепе у рта лежали бронзовое кольцо со щитком (рис. 8,7) и железная пряжка (рис. 9,9), на челюсти лежала серебряная обойма (рис. 8,10), в районе лопатки обнаружены обломки железной пряжки (рис. 9,6), на тазовых костях - серебряная обойма (рис. 8,6).

На высоте 0,9 м от пола погребальной камеры обнаружены зубы ребенка, рядом с ними на одном уровне находились различные вещи (рис. 1). Границы могилы в рухнувшем своде проследить не удалось. В качестве погребального инвентаря были использованы краснолаковые ойнохоя (рис. 6,4) и миска (рис. 6,5), железный нож (рис. 6,6), керамическое пряслице (рис. 6,2), бусы (рис. 7,6-27, 14,6), серебряная подвеска-лунница (рис. 7,4), железная фибула (рис. 7,5), бронзовый наконечник ремня (рис. 6,3), две серебряные серь- 
ги, лицевые стороны которых покрыты золотой орнаментированной фольгой и украшены сердоликовыми вставками (рис. 7,1,2), серебряный перстень, щиток которого украшен сердоликом (рис. 7,3).

Сделаны антропологические определения двух костяков. Погребение II - мужчина 45-55 лет; погребение III - мужчина 50+ лет.

Из описания видно, что речь идет о двух погребальных сооружениях, склепе и детской могиле. Их относительная хронология не ясна. Детская могила могла быть выкопана позже склепа, над его погребальной камерой. Возможен и другой вариант. Детскую могилу выкопали раньше, а строители склепа устроили под ней погребальную камеру. Отдать предпочтение одному из вариантов невозможно. В обоих случаях свод склепа через какое-то время после его сооружения рухнул и детская могила провалилась.

Публикуемый склеп, состоящий из входной ямы, дромоса и погребальной камеры, относится к группе погребальных сооружений позднеримского времени, хорошо известной в Крымских предгорьях. Только в могильнике Нейзац открыто 87 таких склепов. Они являются одним из самых характерных элементов нейзацкой археологической культуры [Мульд, 2016, с. 40-45; Храпунов, 2019, с. 33]. Несмотря на общее конструктивное сходство и зафиксированные обряды, которые можно назвать, в целом, стандартными, каждый склеп имеет, как правило, какие-то индивидуальные особенности. В нашем случае это погребение всех людей в деревянных конструкциях. Аналоги им, конечно, известны и в склепах, и в подбойных, и в грунтовых могилах. В большинстве склепов остатков дерева нет. Там, где гробы зафиксированы, в них, как правило, хоронили одного-двух из четырех-восьми погребенных в склепе.

Остатки деревянных конструкций вполне логично принято именовать гробами. Смущает то обстоятельство, что ни в одном случае не отмечены следы ни дна, ни крышки. В нашем случае положение останков погребенного I предполагает, что он был положен в гроб на спину с согнутыми в коленях ногами. Следовательно, крышки у такой конструкции быть не могло.
Ориентация склепов и, как следствие, похороненных в них людей зависела от ориентации склона, в котором устроен могильник, и не является культурообразующим признаком. Однако следует отметить, что в подавляющем большинстве случаев погребенных укладывали ногами к входу в погребальную камеру. Ситуация, когда всех погребенных поместили головой к входу, является редчайшим исключением из правил.

Обращает на себя внимание наличие останков лошади, разрубленной на куски и сложенной в относительном анатомическом порядке у южной стены погребальной камеры. Случай редкий, но не уникальный. Точно такая же ситуация зафиксирована в склепах IV в. н.э. № 78 в могильнике Дружное [Храпунов, 2002 , с. 33 , рис. 58 ] и № 4 в могильнике Нейзац [Храпунов, 2008а, с. 360, рис. 2]. Кроме того, в погребальных камерах нескольких разграбленных склепов этих могильников обнаружено значительное количество лошадиных костей, что позволяет предполагать наличие конских погребений.

Позы погребенных, кроме погребения I, положение погребального инвентаря, за исключением бус в погребении IV, и его ассортимент, наличие костей животных рядом с ножами обычны для нейзацкой археологической культуры.

Перейдем к анализу погребального инвентаря из погребальной камеры.

Серебряные и бронзовые пряжки. Изучением пряжек римского времени занимались многие исследователи. Их усилиями выявлены признаки, отражающие морфологические, стилистические и хронологические особенности изделий. Общим признаком для подавляющего большинства пряжек позднеримского времени является овальная утолщенная в передней части рамка. Им обладают все публикуемые пряжки. В числе важных особенностей можно назвать прогнутость язычка. Этот признак характерен для пряжек III в. н.э. В склепе № 133 язычок прогнут, да и то незначительно, только у одной бронзовой пряжки (рис. 8,9). Степень загнутости конца язычка за рамку отражает хронологическую позицию пряжки. В общем виде можно сказать, что чем больше конец язычка загнут, тем моложе пряжка. У трех пряжек конец язычка ле- 
жит на крае рамки (рис. 8,4,12,14), в остальных случаях он загнут, но незначительно, порой едва заметно (рис. 8,1-3,5,9,15, 14,1-4). Прямоугольная, порой орнаментированная площадка и ступенчатый срез в тыльной части язычка (рис. 8,1,2,5,9,15) считаются поздними признаками для пряжек позднеримского времени, характерными для IV в. н.э. Ювелирный прием фасетировки, как на двух публикуемых пряжках (рис. 8,3,15), был чрезвычайно распространен в конце II - III в. н.э., в IV в. н.э. встречается в качестве редчайшего исключения. Уже приходилось отмечать, что сочетание «ранних» и «поздних» признаков в одних комплексах, а порой и на одних экземплярах, характерно для III в. н.э. В IV в. н.э. пряжки стандартизируются [Храпунов, 2016, с. 103].

Отдельного внимания заслуживают пряжки, на конец язычков которых нанесены по две точки, по-видимому, имитирующих глаза и придающих язычку черты зооморфизма (рис. 8,4,12,14). Пряжки с зооморфными язычками, конечно, хорошо известны и на территории Римской империи, и в Барбарикуме. Возникла даже дискуссия об их происхождении [Васильев, 2010, с. 103, 104; Kazanski, 2011]. Однако в Крыму в позднеримское время они буквально единичны [Труфанов, Колтухов, 2001-2002, с. 286,294 , рис. 12,11$]$.

Обоймы. Обнаружены три серебряные обоймы. Эти изделия, изготовленные из согнутых пополам пластин, имевшие валик в месте перегиба и скрепленные одной заклепкой каждое (рис. 8,6,10,16).

Наиболее ранние изделия такого типа обнаружены в Золотом кладбище на Кубани [Гущина, Засецкая, 1994, кат. № 21, 397, 546], в III-V вв. они распространяются на Северном Кавказе [Абрамова, 1997, с. 117; Габуев, Малашев, 2009, с. 125], на Нижнем Дону характерны для комплексов IV в. н.э. [Безуглов, Захаров, 1988, с. 19]. В Крыму они найдены в комплексах III в. н.э. могильника Нейзац [Храпунов, 2006, с. 110, рис. 4,13; 2011a, с. 14 , рис. 15,7,12,15,19-2], склепах IV в. н.э. могильников Суворово [Зайцев, 1997, с. 110, рис. 61] и Дружное [Храпунов, 2002, с. 44], в подбойной могиле IV в. н.э. некрополя Алмалык-Дере [Mączyńska et al., 2016, S. 111, Taf. 64,3], многочисленны в погребениях V в. н.э. боспорских склепов [Засецкая, 1993, с. 44, 61, 91, табл. 13,34, 28,128, 129, 61,358].

Обоймы надевались на края кожаных и деревянных предметов, поэтому в них сохраняется иногда кожаный, иногда древесный тлен.

Наконечники ремней. Пара серебряных двухчастных, украшенных фасетками и насечками наконечников. Подвески имеют треугольное расширение в нижней части (рис. 10,6,7, 13,9, 10). Соответствуют типу Н6 по классификации В.Ю. Малашева, который датируется, по его мнению, концом III - первыми десятилетиями IV в. н.э. [Малашев, 2000, с. 197, $202,207]$. Ближайшие аналогии публикуемым наконечникам происходят из склепа, раскопанного В. Шкорпилом в Керчи в 1841 г. [Малашев, 2000, рис. 12Б]. Вероятно, к тому же или очень близкому типу принадлежал серебряный фрагментированный наконечник, от которого сохранились части фасетированной пластины и треугольной подвески (рис. 10,8). Еще от одного наконечника сохранилась только серебряная подвеска, которая не дает возможности определить тип, но ясно, что она датируется в пределах III-IV вв. н.э. (рис. 10,1, 13,8).

Гребень костяной (рис. $10,11,14,5)$ относится к типу Томас III. Изделия этого типа датируются Сигрид Томас второй половиной IV - V в. н.э. [Thomas, 1960, S. 104-114]. Максимальная концентрация гребней типа Томас III отмечена в ареале черняховской культуры. Судя по материалам этой культуры, гребни с выступающей средней частью спинки появились раньше, чем думала Томас, но в пределах IV в. н.э. Прослежена тенденция, в соответствии с которой, чем выше центральная часть спинки, тем более поздним временем датируется изделие [Магомедов, 2001, с. 84]. В нашем случае утрачена как раз выступающая часть спинки. Поэтому детали выяснить нельзя.

Все исследователи согласны с тем, что костяные гребни попали в Крым с территорий, заселенных восточногерманскими племенами [Кропоткин, 1978, с. 153; Пиоро, 1990, c. 101, 103; Казанский, 1999, с. 277].

Фибула железная, к сожалению, настолько деформирована коррозией, что определить ее тип не представляется возможным (рис. 10,9). 
Tопор железный с прямым верхним краем, серповидным лезвием и выделенным обухом (рис. 11,1). Последняя особенность сближает его почти со всеми топорами позднеримского времени, найденными в Крыму (сводку см.: [Kazanski, 1994, s. 456-458]; новые находки: [Вознесенская, Левада, 1999, с. 256, 257; Храпунов, 2002, с. 51-52; Мыц и др., 2006, c. 123; Контны, Савеля, 2006, с. 136-138]), а также в Абхазии [Воронов, Шенкао, 1982, c. 27]. Уже приходилось писать о том, что крымские и абхазские топоры в подавляющем большинстве случаев отличаются от синхронных им германских, они, по-видимому, местного производства [Храпунов, 2010, с. 548; 2011б, с. 32].

Ведерковидные подвески железные (рис. 12,4). Украшения этого типа были широко распространены в Европейском Барбарикуме, в том числе и в Крыму. Опушкинские находки соответствуют типу А, варианту II по классификации И. Байлке-Фойгт [Beilke-Voigt, 1998, S. 52]. В Крыму железные ведерковидные подвески встречаются гораздо реже, чем бронзовые. Они использовались на протяжении всего позднеримского периода [Стоянова, 2016, с. 130-132]. Работая с черняховскими материалами, О.В. Гопкало отметила, что маленькие подвески, подобные публикуемым, датируются более ранним временем, чем крупные экземпляры, диаметр которых превышает 1,5 см [Гопкало, 2008, с. 64].

Стрелковидная подвеска из гагата (рис. 10,2). Соответствует типу 84 по классификации Е.М. Алексеевой. Такие подвески были достаточно распространены в Северном Причерноморье. Они датируются, по мнению Е.М. Алексеевой, преимущественно I в. н.э. [Алексеева, 1978, с. 18].

Кремни (рис. 12,14,21,25). Обработанные кремни не раз находили в крымских могилах римского времени. Назначение их оставалось не ясным. Петр Мончинский и Беата Полит обратили внимание на весьма распространенную, особенно в склепах IV в. н.э., категорию находок - железные стержневидные предметы с деревянными ручками. Обычно их называли шильями (см., например: [Храпунов, 2011б, с. 40]). Оказалось, что весьма часто железные стержневидные предметы, также как в публикуемом склепе (рис. 9,
$12,14)$, находят в одних комплексах с кремневыми изделиями. Это обстоятельство, а также аналогии из Центральной и Северной Европы, позволили предположить, что в Крыму в качестве погребального инвентаря использовались огнива, состоящие из железных стержневидных кресал с деревянными ручками и кремней. Для высекания огня применялись отщепы, пластины, орудия на пластинах, бифациальные орудия, в одном случае нуклеус. Вероятнее всего, их находили на месте стоянок каменного века, хотя нельзя исключить производство, например, отщепов и в римское время [Mączyński, Polit, 2016a; 2016b].

Монеты ${ }^{2}$.

№ 1 (рис. 13,1).

определение: Юлия Домна. Выпуск ок. 211-217 гг., времени правления ее сына Каракаллы. Место чеканки: Рим. Серебро. Номинал:денарий.

Л. c.: Бюст императрицы, задрапированный, вправо; волосы уложены аккуратными волнами и низко спущены сзади. По сторонам надпись: IVLIA PIA - FELIX AVG. Точечный ободок.

O. c.: Диана в рост, в фас, голова влево, в обеих руках держит факел. По сторонам надпись: (D)I[ANA] LVC[IF](ERA).

Сохранность: хорошая. Края заготовки обрезаны неровно. Обе стороны немного неотцентрованы, в результате верхняя часть изображения оказалась вне монетного кружка. По краям о. с. значительные фрагменты коричневой патины. Диаметр: 18-20 мм, толщина: 1 мм. Bec: 2,26 г. Соотношение осей: $12: 12$.

Аналогия в каталоге: [Mattingly, Sydanham, 1936, p. 272, no. 373A, pl. XIII.16]. Аналогия в Крыму: Нейзац, мог. 62, № 2 [Храпунов, 2009, с. 57 , рис. 1,4 , с. 58 , № 4].

№ 2 (рис. 13,5).

Определение: Гордиан III. Выпуск 240 г. Место чеканки: Рим. Серебро. Номинал/тип: антониниан. Юбилейный выпуск в честь тысячелетия Рима.

Л. $c .:$ Бюст императора в лучистой короне, задрапированный, в кирасе, вправо. Вокруг надпись: IMP. CAES. M. ANT. GORDIANVS AVG. Точечный ободок.

O. c.: Рома (олицетворяла город Рим), в воинской одежде и шлеме, сидит на щите 
над чертой, влево; в левой руке держит скипетр, в протянутой правой - Победу, которая протягивает ей венок. Вокруг надпись: ROMAEAETERNAE. Точечный ободок.

Сохранность: очень хорошая. Обе стороны немного неотцентрованы. Незначительные следы коричневой патины. Диаметр: 2123 мм, толщина: 2 мм. Вес: 3,94 г. Соотношение осей: $12: 1$.

Аналогии в каталоге: [Mattingly et al., 1949 , p. 5, 19, no. 38, pl. 1.14].

№ 3 (рис. 13,4).

Определение: Гордиан III. Третий выпуск (240 г.). Место чеканки: Рим. Серебро. Номинал/тип: антониниан.

J. $\boldsymbol{c . :}$ Бюст императора в лучистой короне, задрапированный, в кирасе, вправо. Вокруг надпись: IMP. GORDIANVS PIVSFEL. AVG. Точечный ободок.

$\boldsymbol{O}$. $\boldsymbol{c} .:$ Фигура Либералитас (олицетворяла щедрость), в рост, задрапированная, голова влево, в правой руке держит абак, в левой рог изобилия. Вокруг надпись: LIBERALITAS AVG. III. Точечный ободок.

Сохранность: очень хорошая. О. с. немного не отцентрована. Незначительные следы коричневой патины. Диаметр: 21-23 мм, толщина: 2 мм. Вес: 3,76 г. Соотношение осей: $12: 12$.

Аналогии в каталоге: [Mattingly et al., 1949 , p. 23, no. 67, pl. 2.1, о дате: p. 5-6; Фролова, Абрамзон, 2003, с. 116-117, № 31].

Аналогия в Крыму: Совхоз «Севастопольский» (Совхоз № 10), грунтовая могила с каменным ящиком № 47 [Стржелецкий и др., 2003-2004, c. 265, № 14].

№ 4 (рис. 13,2).

Определение: Гордиан III. Выпуск 242 244 гг. Место чеканки: Антиохия. Серебро. Номинал/тип: антониниан.

Л. $\boldsymbol{c}$ : Бюст безбородого императора в лучистой короне, задрапированный, вправо. Вокруг надпись: IMP. GOR[DIANV]SPIVSFEL. AVG. Точечный ободок.

O. $\boldsymbol{c}$ : Фигура императора в рост, вправо, в правой руке держит копье, в левой - шар. Вокруг надпись: SAECVLI (F-E)-LICITAS. Точечный ободок.

Cохранность: хорошая. Отчеканена на овальной заготовке, немного не отцентрована. Легенда частично стерта. Незначитель- ные следы коричневой патины. Диаметр: 2124 мм, толщина: 1 мм. Bec: 2,32 г. Соотношение осей: $12: 1$.

Аналогии в каталоге: [Mattingly et al., 1949 , p. 37, no. 216, pl. 3.16].

№ 5 (рис. 13,3).

Определение: Филипп I Араб. Недатированный выпуск, 244-247 гг. Место чекана: Рим. Серебро. Номинал/тип: антониниан.

J. $\boldsymbol{c}$ : : Бюст бородатого императора, в лучистой короне и кирасе, задрапированный, вправо. Вокруг надпись: IMP. M. IVL. PHILIPPVSAVG. Точечный ободок.

O. $\boldsymbol{c . : ~ Ф и г у р а ~ Э к в и т а с , ~ в ~ р о с т , ~ з а д р а п и р о - ~}$ ванная, в короне, влево, в левой руке держит рог изобилия, в протянутой вперед правой весы. Вокруг надпись: AEQVITASAVGG. Toчечный ободок.

Сохранность: хорошая. Обе стороны немного неотцентрованы. Незначительные следы коричневой патины. Диаметр: 21-22 мм, толщина: 1 мм. Вес: 2,58 г. Соотношение осей: $12: 1$.

Аналогии в каталоге: [Mattingly et al., 1949, p. 71, no. 27b].

№ 6 (рис. 13,6).

Определение: Траян Деций. Выпуск 249251 гг. Место чекана: Рим. Серебро. Номинал/тип: антониниан.

Л. $\boldsymbol{c}$ : Бюст императора, в лучистой короне и кирасе, задрапированный, вправо. Вокруг надпись: [IMPC.M. Q. TRAI]ANVSDECIVSAVG. Точечный ободок.

$\boldsymbol{O}$. $\boldsymbol{c}$ : Фигура Паннонии (олицетворение соответствующей провинции) в рост, влево, задрапированная, в правой руке держит венок (?), в левой - воинский штандарт. Вокруг надпись: PANNON(I)AE. Точечный ободок.

Сохранность: плохая. Поверхность покрыта зеленой и коричневой патиной. Отчеканена на овальной заготовке, края обрезаны неровно. Обе стороны плохо отцентрованы. Диаметр: 21-23 мм, толщина: 1 мм. Вес: 2,74 г. Соотношение осей: $12: 1$.

Аналогии в каталоге: [Mattingly et al., 1949, p. 122, no. 20].

Кольиа с зажимами серебряные и бронзовые (рис. 8,7,8,11,13).

Аналогичные предметы являются обычной находкой в позднесарматских погребениях восточноевропейской степи и особенно в 
крымских комплексах III-V вв. н.э. Их крепили к конской сбруе, к ремням, надетым на людей, к краям деревянных сосудов (см., например: [Безуглов, 1988, с. 107, рис. 3,20,21; Храпунов, 2002, рис. 73,5, 75, 15, 80,4,7, 143,5, 170,5, 177,2, 182,2; Высотская, 1998, рис. 5,14; Скрипкин, 1984, с. 41, рис. 15,16 ; Гудкова, Фокеев, 1984, с. 47 , рис. 14,16; Гущина, Засецкая, 1994, кат. № 73, 550, 556 и др.; Веймарн, 1963 , с. 27,37 , рис. $21,2,3$; Лобода, 1977, с. 245 , рис. 6,20 ; Засецкая, 1993 , с. 44 , табл. 13,31 ; Айбабин, Хайрединова, 1998, рис. 16,3,4,1618; Габуев, Малашев, 2009, с. 27, рис. 35,5-8; Бруяко и др., 2017, с. 252, рис. 3,7-9; Ворошилов, 2018, с. 51, рис. 5,4,5; Mączyńska et al., 2016, S. 111, Taf. 64,2]).

Лепные сосуды (рис. 6,1, 10,10, 12,1).

Лепные сосуды по форме, составу глины, характеру обработки поверхности соответствуют многим экземплярам, найденным в погребениях Крымских предгорий. Они являются одним из самых характерных признаков нейзацкой археологической культуры. Подавляющее большинство лепных сосудов обнаружено в погребениях IV в. н.э. В погребениях III в. н.э. они встречаются редко [Власов, 1999; Храпунов, 2019, с. 34, 37, 43].

Бусы (рис. 10,3-5, 12,3,5-13,15-20,22$24,26-34,14,7)$.

В погребении II найдена одна бусина, использовавшаяся, вероятно, в качестве застежки [Хайрединова, 1995, с. 80; Стоянова, 2004 , с. 302]. Рядом с костями ног скелета в погребении IV обнаружены лежавшие компактно 563 бусины и многочисленные фрагменты от разложившихся экземпляров. Ими, очевидно, был обшит какой-то предмет из органического материала. Основу набора бус составляли стеклянные цилиндрические и призматические экземпляры, а также шаровидные из стекла с внутренней металлической прокладкой. Они дополнялись 14-гранными и шаровидными из одноцветного стекла. В целом состав бус соответствует второй группе, выделенной А.А. Стояновой по материалам крымских комплексов конца II - первой половины III в. н.э. и группе 5 бус из могильника Нейзац [Стоянова, 2010, с. 406; 2011, с. 120]. Отличие заключается в наличии в публикуемом комплексе 52 короткоцилиндрических гагатовых бусин.
В детском погребении над погребальной камерой найдены следующие вещи.

Краснолаковая ойнохоя понтийского производства (рис. 6,4). Точных аналогий найти не удалось. В то же время нельзя не отметить, что по форме тулова этот сосуд соответствует кувшинам типа 2 по классификации О.В. Шарова [Шаров, 2007, с. 46-49], форме 39 по классификации Д.В. Журавлева [Журавлев, 2010, с. 89, 90]. Много таких кувшинов обнаружено в крымских комплексах III в. н.э., но в некрополе Дружное они найдены в могилах IV в. н.э. [Храпунов, 2002, с. 59, 60].

Миска краснолаковая (рис. 6,5). Относится к группе понтийской сигиллаты А. Соответствует форме 14 по классификации Д.В. Журавлева с датой: конец I - середина III в. н.э. [Журавлев, 2010, с. 54, 55].

Фибула железная (рис. 7,5). Сильно коррозирована и фрагментирована. Определить ее тип не удалось.

Серьги серебряные (рис. 7,1,2). Состоят из проволочной дужки и овального щитка. Замок сделан в виде крючка, которым заканчивается дужка, с петелькой, припаянной к щитку. Щиток состоит из двух пластин - тыльной и лицевой. Лицевая пластина покрыта серебряной позолоченной фольгой, крепившейся двумя гвоздиками с полусферическими шляпками. Фольга украшена рельефным тисненым орнаментом. В центре щитка располагалось гнездо со вставкой. Во вставках в обеих серьгах находились сердолики, но разных оттенков красного. К дужкам подвешены подвески в виде стилизованных гроздей винограда. В могильнике Опушки найдены, кроме публикуемой, еще три пары однотипных серег. Все они опубликованы [Храпунов, Стоянова, 2018]. Вещи из предгорного Крыма, изготовленные в догуннском полихромном стиле, представляют собой украшения. В этом заключается ареальное отличие от территории Боспорского царства, Нижнего Подонья, Северо-Западного Причерноморья, где преобладают детали конской сбруи, дополняемые предметами вооружения и украшениями. Во всех ареалах вещи в догуннском полихромном стиле датируются преимущественно второй половиной III - первой половиной IV в. н.э. Изготавливались они в античных центрах, на что, наряду с прочим, указывают подвески в 
виде виноградных гроздьев на публикуемых серьгах.

Наконечника ремня бронзового фрагмент (рис. 6,3). Сохранилась пластинчатая подвеска с прямоугольным отверстием возле верхнего края для соединения с обоймой. Относится к типу Н1 по классификации В.Ю. Малашева. Такие наконечники ремней характерны для позднесарматской культуры. Датируются в пределах второй половины II - первой половины III в. н.э. [Малашев, 2000, с. 197, 199]. Соответствует типу $\mathrm{X}$ наконечников ремней из могильника Нейзац [Храпунов, 2008б, с. 68].

Перстень серебряный (рис. 7,3). Пластинчатый. Края пластины не замкнуты, раскованы и образуют овальный щиток, к которому припаян каст овальной формы, сделанный из поставленной на ребро пластинки и окруженный рифленой проволокой. В каст вставлен сердолик. Перстень принадлежит обладающей общими стилистическими признаками группе украшений, изготовленных, по всей видимости, на Боспоре [Трейстер, 2011; 2015, с. 153]. Последнее обстоятельство позволяет предположить боспорское происхождение и описанной выше пары серег, с которыми перстень составлял парюру. Аналогичное украшение обнаружено в могиле № 124 могильника Опушки [Храпунов, 2018a, с. 142, рис. 10,5].

Подвеска серебряная в виде лунницьь (рис. 7,4). Такие подвески, правда, как правило, большего размера, были распространены на значительных территориях, в том числе и в Крыму. Крымские находки датируются III в. н.э. [Стоянова, 2016, с. 135, 136].

Подвески янтарные восьмерковидные (рис. 7,27, 14,6). Традиционно рассматриваются как вещи, проникавшие в Крым с территорий, заселенных германцами. В Крыму найдено несколько сотен экземпляров, почти исключительно в погребениях IV в. н.э., преимущественно детских [Стоянова, 2016, с. 129].

Бусы (рис. 7,6-26). Набор бус из детского погребения уникален, во всяком случае для Крыма, за счет абсолютного преобладания изделий из янтаря. Из этого материала, не считая 26 восьмерковидных подвесок, сделана 201 бусина из 275 обнаруженных. Стоит добавить, что многие янтарные бусы разло- жились на мелкие фрагменты и учету не поддавались.

Датировка. Главным ориентиром для датировки захоронений в погребальной камере служат сложенные «столбиком» шесть монет, самая поздняя из которых датируется 249-251 гг. н.э. Погребение IV с монетами располагалось вплотную к погребению лошади, находившемуся у южной стены погребальной камеры. От остальных погребений его отделял проход шириной 0,4 м. Погребения IIII располагались вплотную друг к другу. Следовательно, можно предположить, что погребения IV и конское совершались не в одно время с остальными тремя. Однако установить, какие из них совершались раньше, а какие позже невозможно. Поэтому при датировке склепа приходится оперировать всеми находками, сделанными при его раскопках. Наиболее ранними из них являются бусы, набор которых, по аналогиям, можно датировать второй половиной II - первой половиной III в. н.э. В данном случае они найдены рядом с монетами. Следовательно, обшитый бусами предмет использовался не ранее начала второй половины III в. н.э. Набор пряжек следует отнести к III - началу IV в. н.э. Наконечники ремней датируются концом III - первыми десятилетиями IV в. н.э. Самая поздняя находка в погребальной камере - это гребень, который, по существующим материалам, не может датироваться раньше IV в. н.э. Аналогии лепным сосудам также происходят из комплексов IV в. н.э. Обоймы, кольца с зажимами, ведерковидные подвески датируются в пределах III-V вв. н.э. и время совершения захоронений в склепе не уточняют. Таким образом, время сооружения склепа и совершения в нем погребений следует отнести ко второй половине III - началу IV в. н.э.

В погребении ребенка, совершенном над погребальной камерой склепа, есть ранние вещи. Это краснолаковая миска и наконечник ремня, которые относятся ко времени до середины III в. н.э. Подвеска-лунница датируется III в. н.э. Серьги, изготовленные в полихромном стиле позднеримского времени, принято датировать второй половиной III - первой половиной IV в. н.э. Правда, исследования последних лет несколько размывают принятые хронологические границы. Комплекс из 
Нижнего Подонья, где найдена узда в аналогичном стиле, вполне можно датировать первой половиной III в. н.э. [Демиденко, 2016]. Имитация поясной гарнитуры с территории Боспорского царства, сделанная с помощью характерных для полихромного стиля позднеримского времени пряжек и наконечников ремней, обнаружена в погребениях более поздних, чем середина IV в. н.э. [Трейстер, 2017, с. 310]. В пределах III-IV вв. н.э. датируется краснолаковая ойнохоя. Восьмерковидные янтарные подвески в Крыму происходят из погребений главным образом IV в. н.э. Таким образом, погребение ребенка совершили, скорее всего, во второй половине III в. н.э., но не исключена и несколько более ранняя и несколько более поздняя дата.

Заключение. Вторая половина III в. н.э. это время, представленное наименьшим количеством комплексов, если сравнивать с предшествующим и последующим периодами. Точнее сказать, наши возможности выделять комплексы второй половины III в. н.э. очень ограничены. Проблема в малом количестве типов вещей, которые начали производить в это время (монеты, лучковые подвязные двучленные фибулы, ранние типы прогнутых подвязных фибул, изделия в догуннском полихромном стиле, поздний вариант узкогорлых светлоглиняных амфор типа Д). Между тем многие вещи, производство которых началось в первой половине III в. н.э., продолжали изготавливать и во второй половине столетия, не изменились типы погребальных сооружений. Можно сказать почти наверняка, что среди раскопанных могил гораздо больше датирующихся второй половиной ІІІ в. н.э., чем удается выделить исходя из сегодняшнего уровня знаний. Важно и то, что хронологические реперы второй половины III в. н.э. сочетаются в комплексе из склепа № 133 и из детского погребения с большим количеством вещей, имеющих более широкую дату. Таким образом, расширяются наши представления о материальной культуре людей, населявших предгорный Крым в этой трудноуловимой археологическими методами половине столетия.

Рядом со склепом № 133 находился склеп № 124, также сопровождаемый разнообразным инвентарем [Храпунов, 2018а]. Оба склепа близки по времени сооружения, в них най- дено немало очень похожих или аналогичных вещей. Инвентарь публикуемых погребений значительно расширяет имеющуюся источниковую базу.

В публикуемом детском погребении и в склепе № 124 найдены парюры, состоящие из перстня и пары серег. Они сделаны в одном стиле, украшены крупными сердоликовыми вставками. Предгорный Крым представляет собой один из ареалов вещей, изготовленных в полихромном стиле позднеримского времени, причем отличается ярко выраженными особенностями. В отличие от территории Боспорского царства, Нижнего Подонья, СевероЗападного Причерноморья, в предгорном Крыму найдены исключительно украшения, преимущественно серьги. Сложен вопрос о месте производства украшений. Вероятнее всего, мастерские находились в различных античных центрах. В нашем случае на античное производство серег, бесспорно, указывают подвески в виде виноградных гроздей. Выше уже говорилось о том, что перстни, скорее всего, относятся к боспорскому производству. Учитывая, что перстень и пара серег в обоих случаях в могильнике Опушки составляли комплект, есть все основания думать, что на Боспоре были изготовлены все украшения.

В Крыму вещи в полихромном стиле позднеримского времени следует отнести к маркерам высшего социального статуса их владельца. В подавляющем большинстве случаев, как и в публикуемом, они найдены в детских погребениях. Следовательно, статус передавался по наследству [Храпунов, Стоянова, 2018, с. 261].

Конструктивно склеп № 133 принадлежит большой группе погребальных сооружений, распространенных в Крыму в позднеримское время. Их отличительной чертой является короткий дромос между входной ямой и погребальной камерой. Первые, единичные склепы такой конструкции появились в первой половине III в. н.э. Ко второй половине III в. н.э. тоже относятся немногие из них, что, возможно, объясняется отмеченной уже трудностью выделения этого периода по археологическим данным. B IV в. н.э. в таких склепах в крымских предгорьях производилось большинство захоронений. Многие исследователи видят в конструкции склепов свидетельство проник- 
новения в Крым предков средневековых северокавказских алан. У такой точки зрения имеются оппоненты [Храпунов, 2018б].

На примере публикуемых погребений можно попытаться понять источники материальной культуры, сложившейся у населения крымских предгорий в позднеримское время. Для крымских варваров стали привычными, обиходными многие изделия античного производства. Среди публикуемых такими являются краснолаковые сосуды, стеклянные бусы, монеты. Серьги и перстень, украшенные сердоликами, обиходными не назовешь, тем не менее, они были произведены в античной мастерской, скорее всего, на Боспоре.

Серия вещей связана по происхождению с северо-западными по отношению к Крыму, заселенными германцами территориями. Это гребень, янтарные восьмерковидные и железные ведерковидные подвески, а также, вероятно, огнива.

Наибольшее количество из найденных в детском погребении и в склепе № 133 вещей характерны для сарматского ареала и земель, испытывавших значительное сарматское влияние. Это многочисленные пряжки, обоймы, наконечники ремней, кольца с зажимами. Отдельно заслуживает быть отмеченным при- ем фасетировки серебряных и бронзовых изделий - один из главных признаков позднесарматской археологической культуры.

Несомненно, крымскими варварами были произведены не имеющие аналогий за пределами полуострова лепные сосуды и, вероятно, топор.

Таким образом, материальную культуру населения крымских предгорий позднеримского времени можно назвать эклектичной, сложившейся под воздействием разных факторов. В какой мере различные по происхождению компоненты материальной культуры отражают этническую ситуацию - вопрос, требующий специального изучения.

\section{ПРИМЕЧАНИЯ}

${ }^{1}$ Статья подготовлена при финансовой поддержке РФФИ в рамках проекта «Исследования могильника Опушки в Крыму: итоги и перспективы» (№ 20-49-910003).

The study was supported by RFBR in the framework of the project "Studies of the Opushki Cemetery in the Crimea: Results and Prospects" (No. 20-49-910003).

2 Определения и описания монет сделаны Н.И. Храпуновым. 


\section{ИЛЛЮСТРАЦИИ}
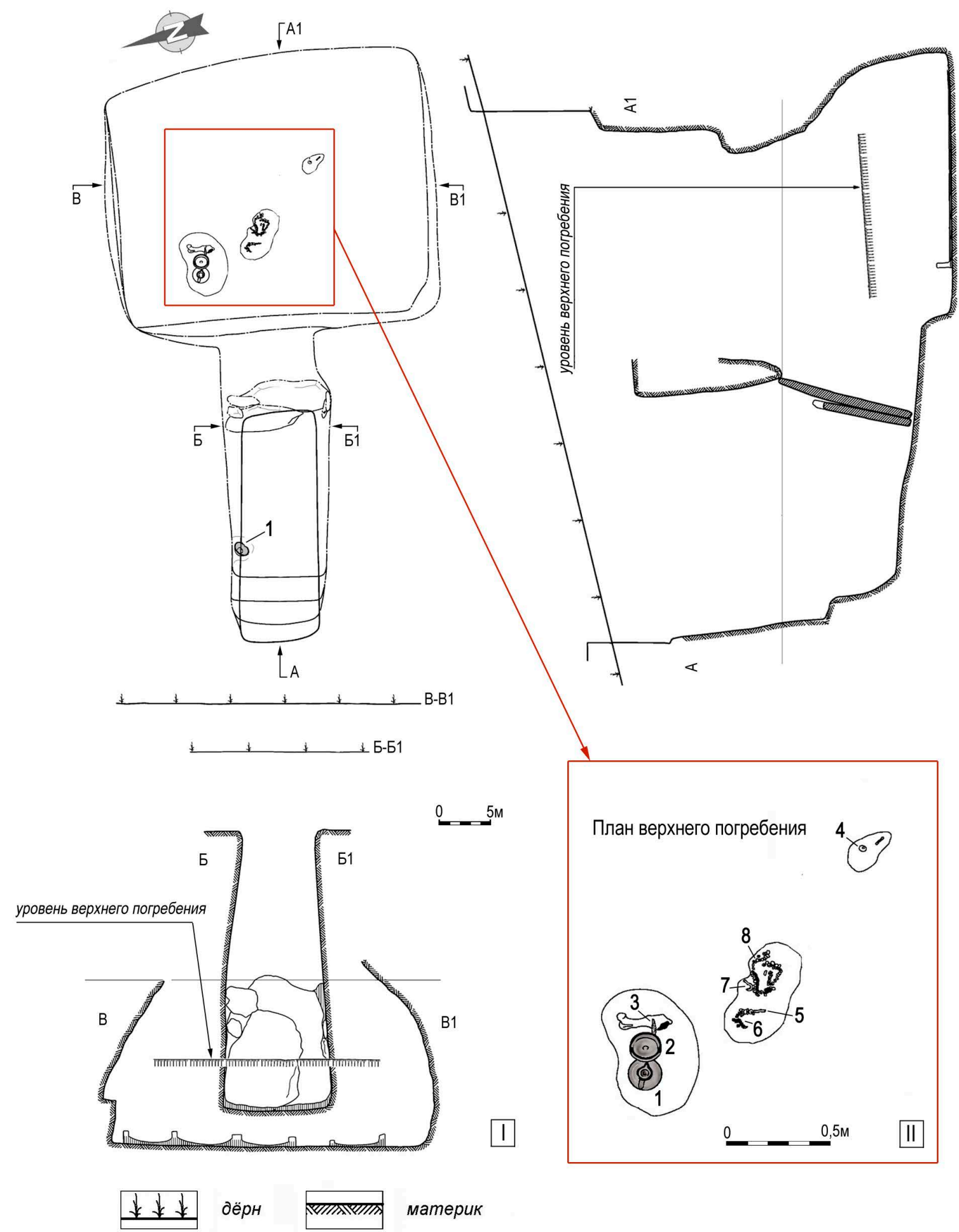

Рис. 1. Могильник Опушки, склеп № 133:

$I$ - план и разрезы: 1 - горшок лепной; $I I$ - план верхнего погребения: 1 - ойнохоя краснолаковая; 2 - миска краснолаковая; 3 - нож железный; 4 - пряслице керамическое; 5, 8- бусы; 6 - подвеска-лунница; 7 - фибула железная (чертеж С.А. Мульда)

Fig. 1. The cemetery of Opushki, burial vault no. 133:

$I$ - ground plan and cross-sections: 1 - hand-formed pot; $I I$ - ground plan of the top burial: 1 - red-slip oenochoe; 2 - red-slip bowl; 3 - iron knife; 4 - ceramic spindle whorl; 5, 8 - beads; 6 - lunula pendant; 7 - iron fibula (drawing: S. A. Mul'd) 


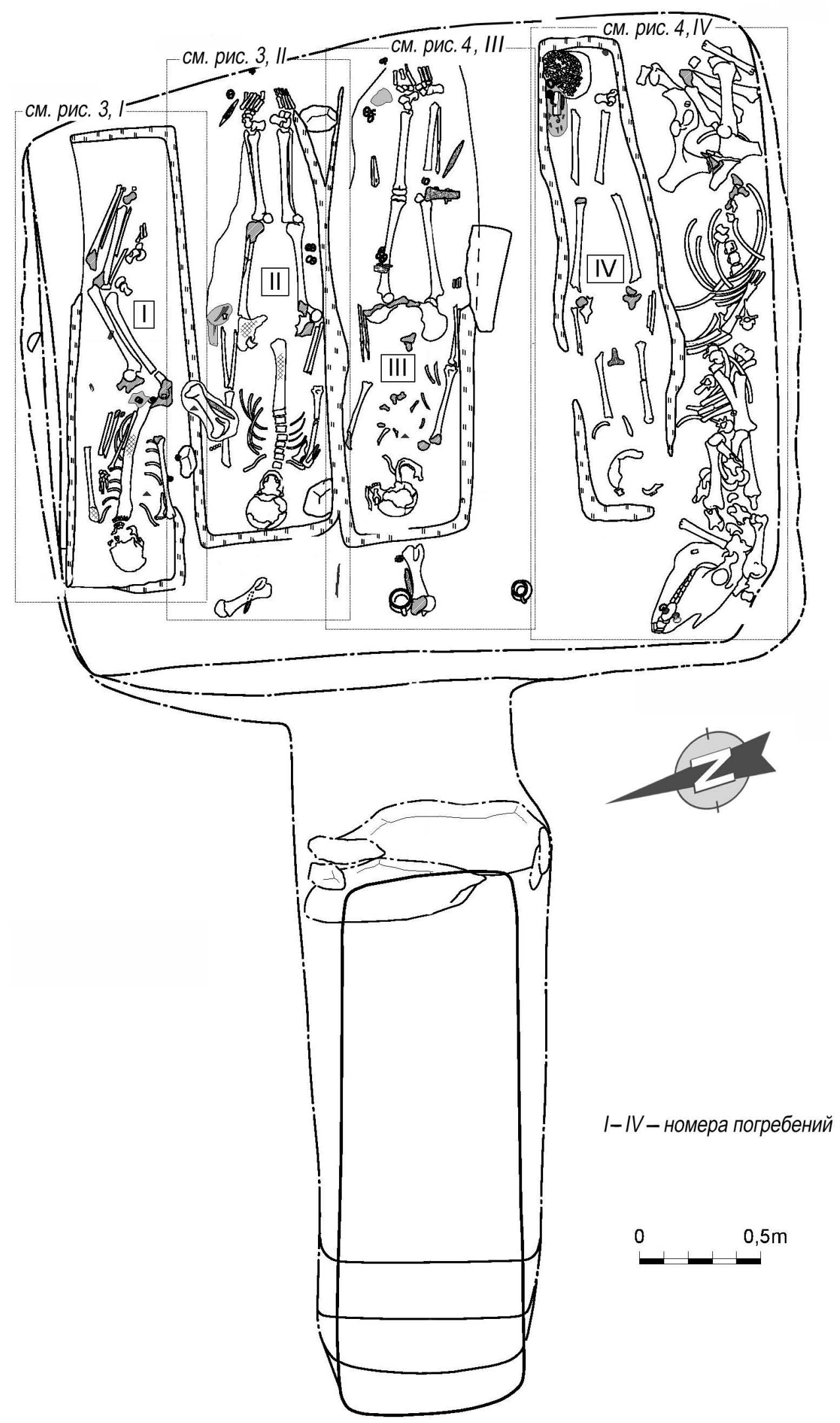

Рис. 2. Могильник Опушки, склеп № 133. Общий план погребений в камере (чертеж С.А. Мульда) Fig. 2. The cemetery of Opushki, burial vault no. 133. General plan of the burials in the burial chamber (drawing: S.A. Mul'd) 

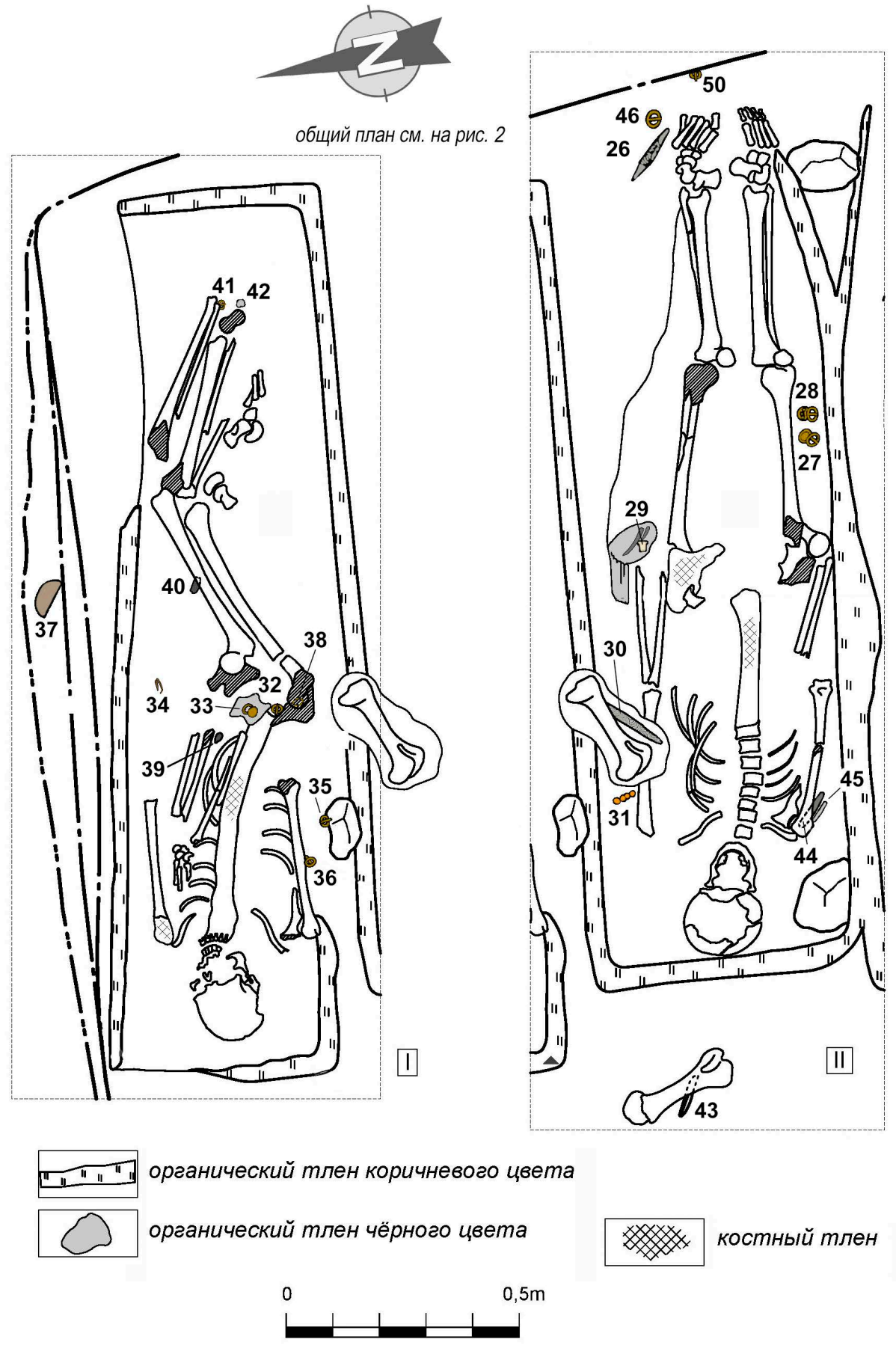

Рис. 3. Могильник Опушки, склеп № 133. Погребения в камере:

$I-I I-$ номера погребений. 26, 30, 45 - ножи железные; 27, 28 - пряжки серебряные;

29 - наконечник ремня из белого металла; 31 - бусы; 32, 33, 35, 38, 41 - пряжки металлические;

34 - накладка на ремень металлическая; 36 - кольцо с зажимом серебряное; 37 - гребень костяной;

39 - предмет железный; 40 - предмет железный стержневидный; 42 - обойма серебряная; 43 - нож железный;

44 - оселок каменный; 46, 50 - пряжки железные (чертеж С.А. Мульда)

Fig. 3. The cemetery of Opushki, burial vault no. 133. The burials in the burial chamber:

$I-I I$ - burial numbers. 26, 30, 45 - iron knives; 27, 28 - silver buckles;

29 - strap-end of a white metal; 31 - beads; 32, 33, 35, 38, 41 - metal buckles;

34 - metal belt fitting; 36 - metal ring with a clamp; 37 - bone comb;

39 - iron artefact; 40 - iron rod-shaped artefact; 42 - silver clip; 43 - iron knife; 44 - stone whetstone; 46, 50 - iron buckles (drawing: S.A. Mul'd) 


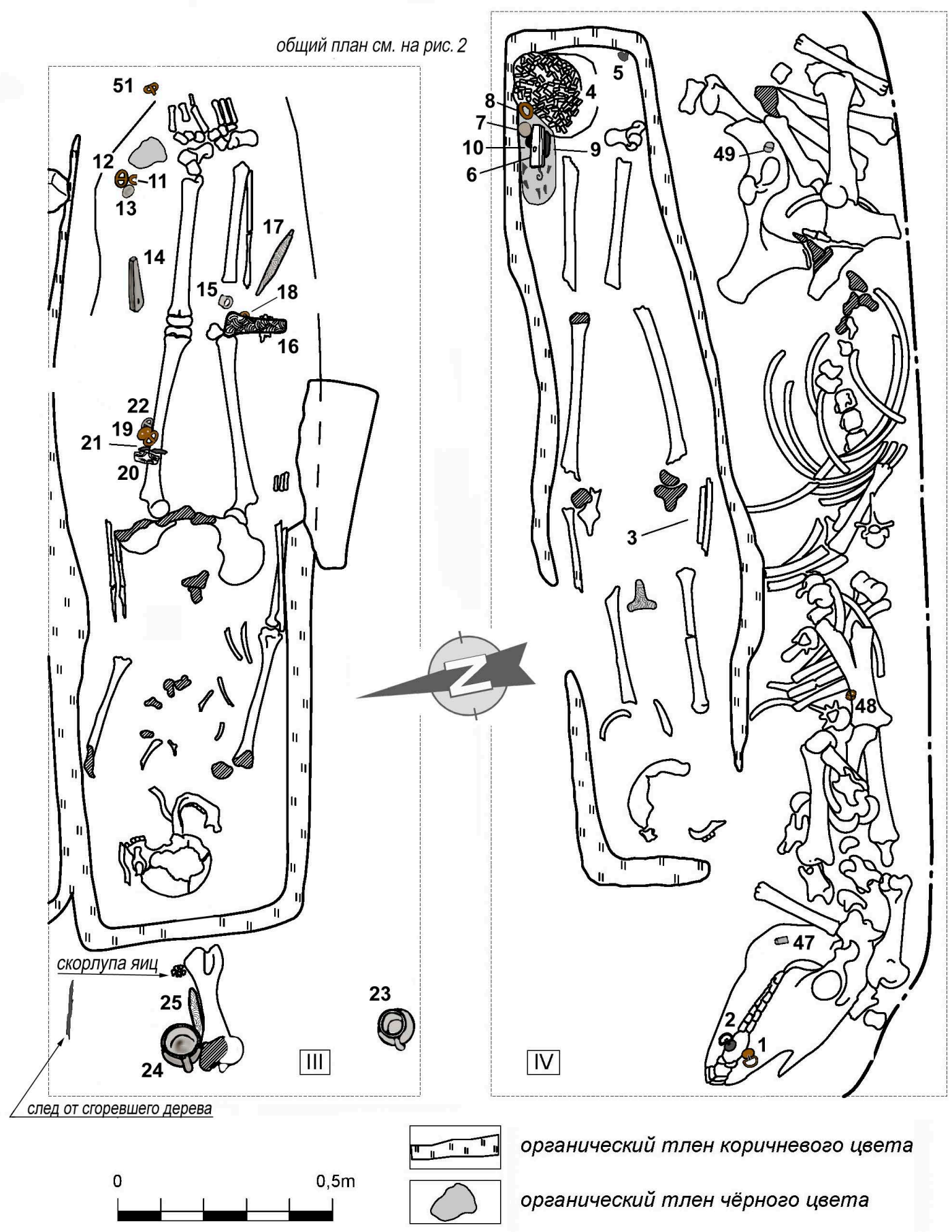

Рис. 4. Могильник Опушки, склеп № 133. Погребения в камере:

$I I I-I V$ - номера погребений. 1 - кольцо бронзовое; 2, 5, 8, 12, 48, 51 - пряжки железные; 3 - фибула железная; 4 - бусы; 6-камень точильный; 7 - монеты; 9, 13, 20 - отщеп кремневый; 10, 21 - предметы железные стержневидные;

11 - предмета бронзового фрагменты; 14 - оселок каменный; 15 - кольцо серебряное; 16 - топор железный;

17, 25 - ножи железные; 18 - кольцо с зажимом бронзовое; 19 - пряжка бронзовая; 22 - пряжка серебряная; 23, 24 - сосуды лепные; 47, 49 - обоймы серебряные (чертеж С.А. Мульда)

Fig. 4. The cemetery of Opushki, burial vault no. 133. Burials in the burial chamber:

$I I I-I V$ - burial numbers. 1 - bronze ring; 2, 5, 8, 12, 48, 51 - iron buckles; 3 - iron fibula;

4 - beads; 6 - grindstone; 7 - coins; 9, 13, 20 - stone flake; 10, 21 - iron rod-shaped artefacts;

11 - bronze artefact fragments; 14 - stone whetstone; 15 - silver ring; 16 - iron axe;

17, 25 - iron knives; 18 - bronze ring with a clamp; 19 - bronze buckle; 22 - silver buckle; 23, 24 - hand-made vessels; 47, 49 - silver clips (drawing: S.A. Mul'd) 


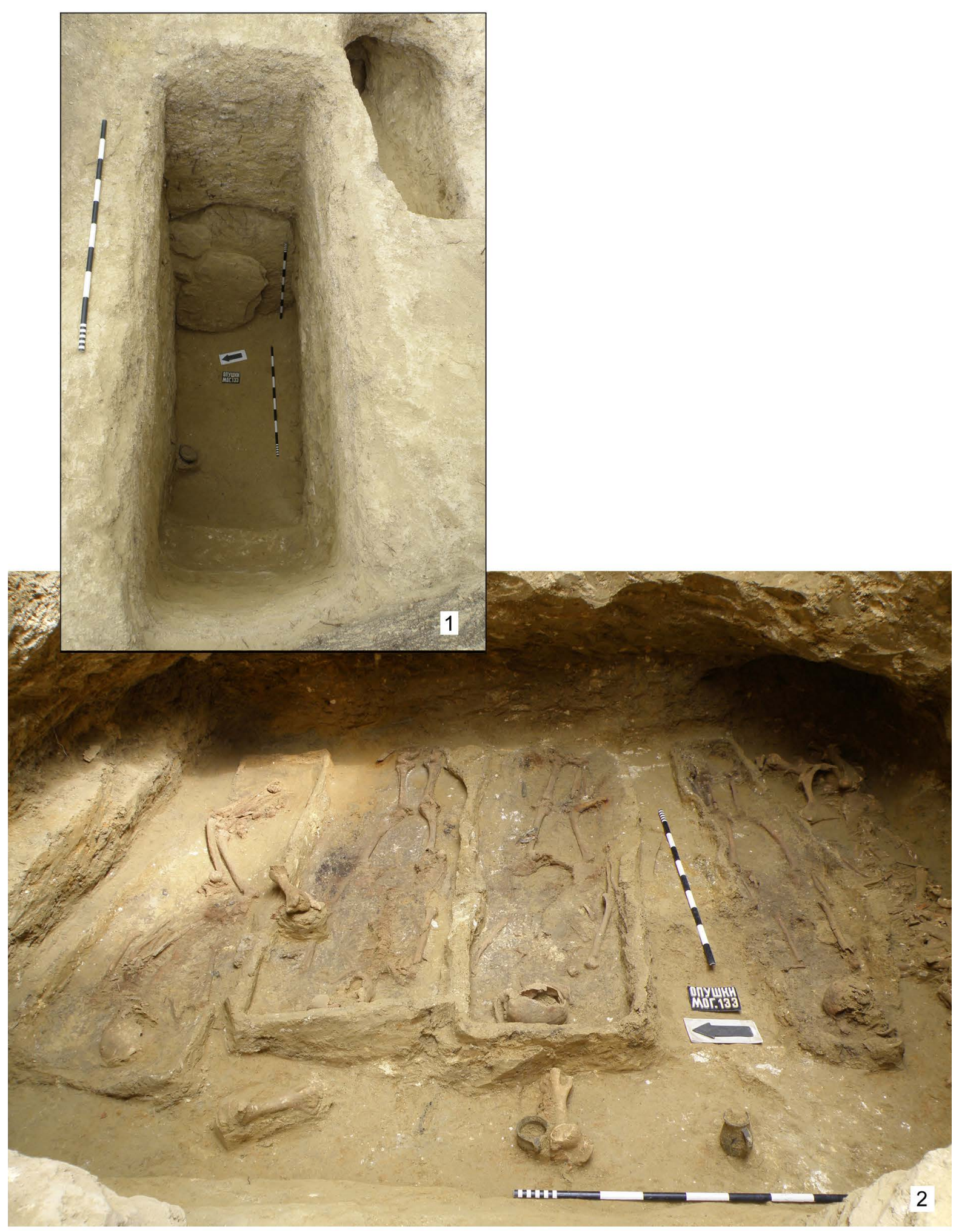

Рис. 5. Могильник Опушки, склеп № 133:

1 - входная яма и каменный заклад в камеру; 2 - погребения в камере (фото С.А. Мульда)

Fig. 5. The cemetery of Opushki, burial vault no. 133:

1 - entrance pit and the stone barrier blocking the passage to the burial chamber;

$2-$ burials in the burial chamber (photo: S.A. Mul'd) 

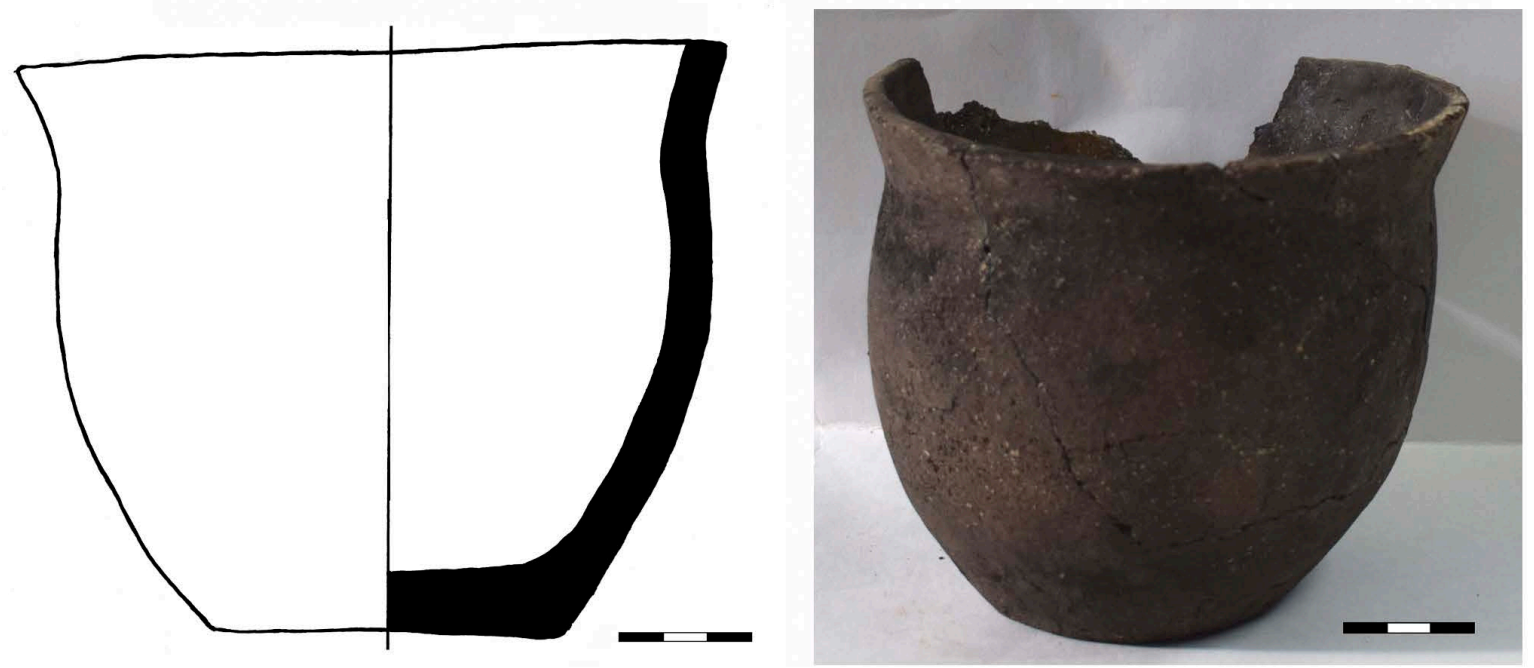

1
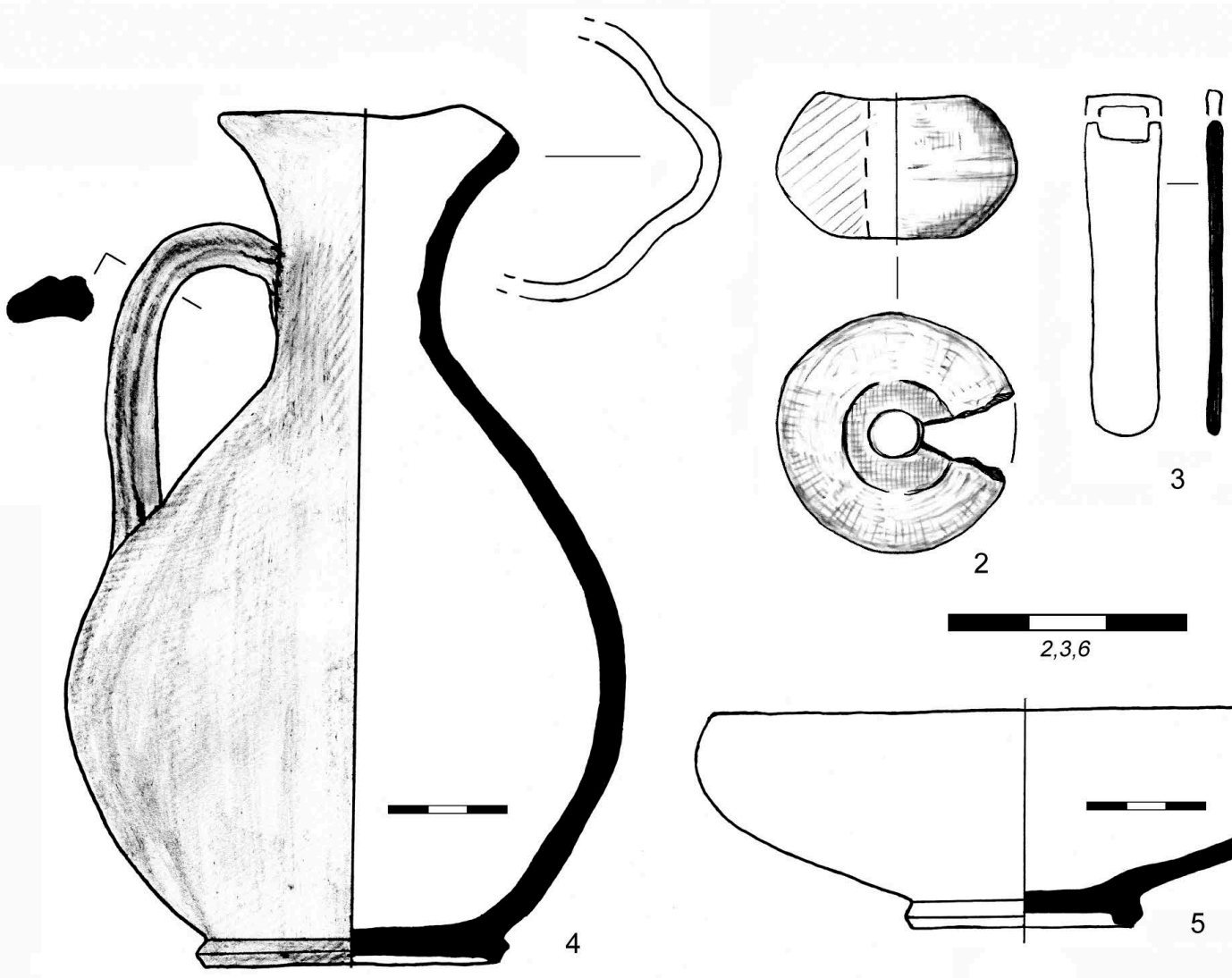

3

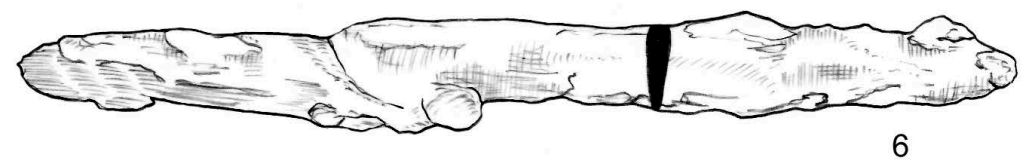

Рис. 6. Могильник Опушки, склеп № 133. Погребальный инвентарь:

1 - входная яма, лепной сосуд; 2-6 - погребение над сводом камеры: 2 - пряслице керамическое;

3 - наконечник ремня; 4 - ойнахоя; 5 - краснолаковая миска; 6 - железный нож (рисунок С.Б. Шабанова)

Fig. 6. The cemetery of Opushki, burial vault no. 133. Grave goods:

1 - entrance pit, hand-formed vessel; $2-6$ - burial above the burial chamber vaulting: 2 - ceramic spindle whorl; 3 - strap-end; 4 - oenochoe; 5 - red-slip bowl; 6 - iron knife (drawing: S.B. Shabanov) 

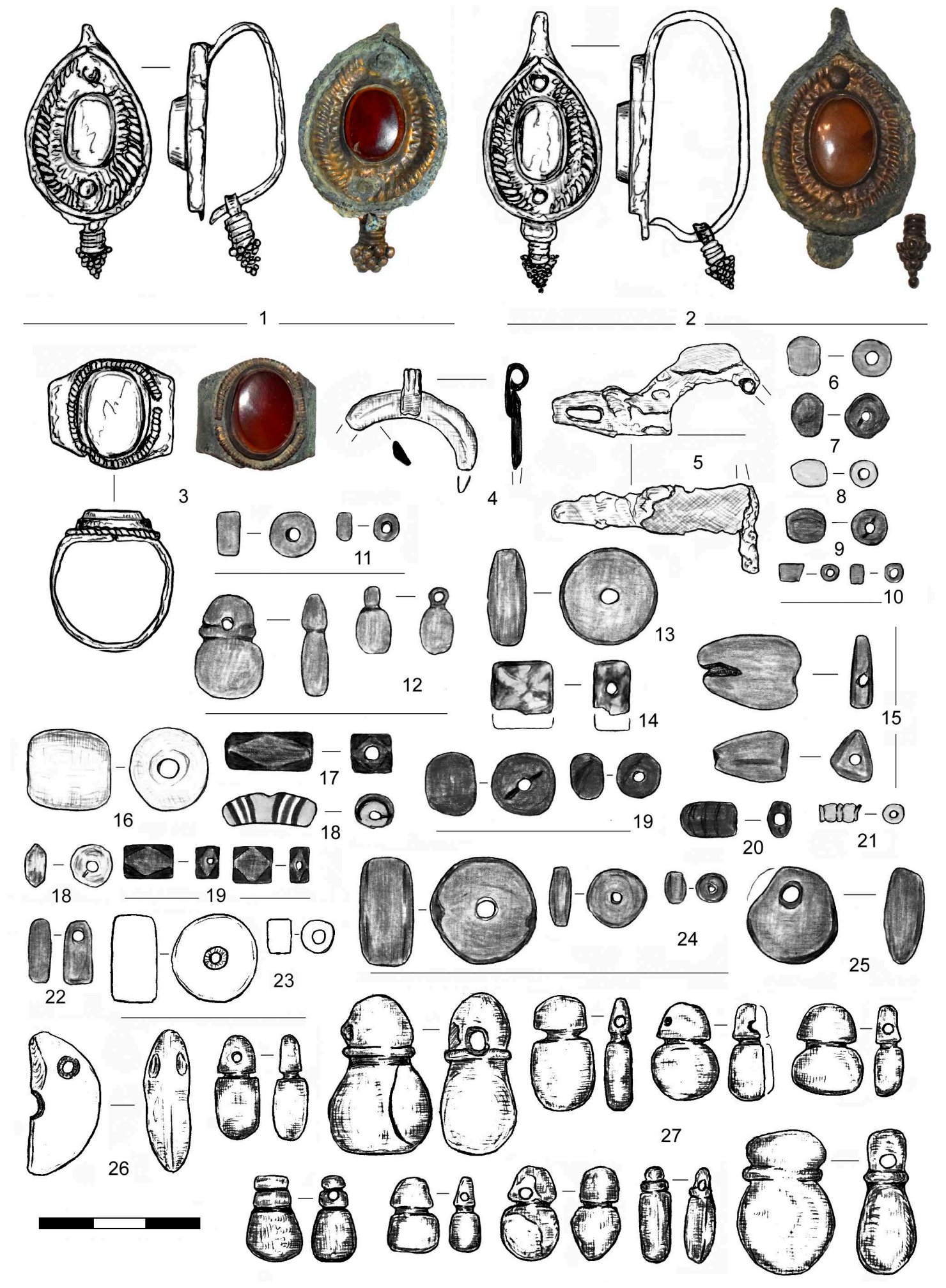

Рис. 7. Могильник Опушки, склеп № 133. Инвентарь погребения над сводом камеры:

1, 2 - серьги серебряные; 3 - серебряный перстень; 4 - лунница серебряная; 5 - железная фибула; 6-11, 13-25 - бусы; 12, 26, 27 - подвески из янтаря (рисунок, фото А.А. Стояновой, С.Б. Шабанова)

Fig. 7. The cemetery of Opushki, burial vault no. 133. Grave goods from the burial above the burial chamber vaulting:

1, 2 - silver earrings; 3 - silver finger-ring; 4 - silver lunula pendant; 5 - iron fibula; 6-11, 13-25 - beads; 12, 26, 27 - amber pendants (drawing and photo: A.A. Stoyanova, S.B. Shabanov) 

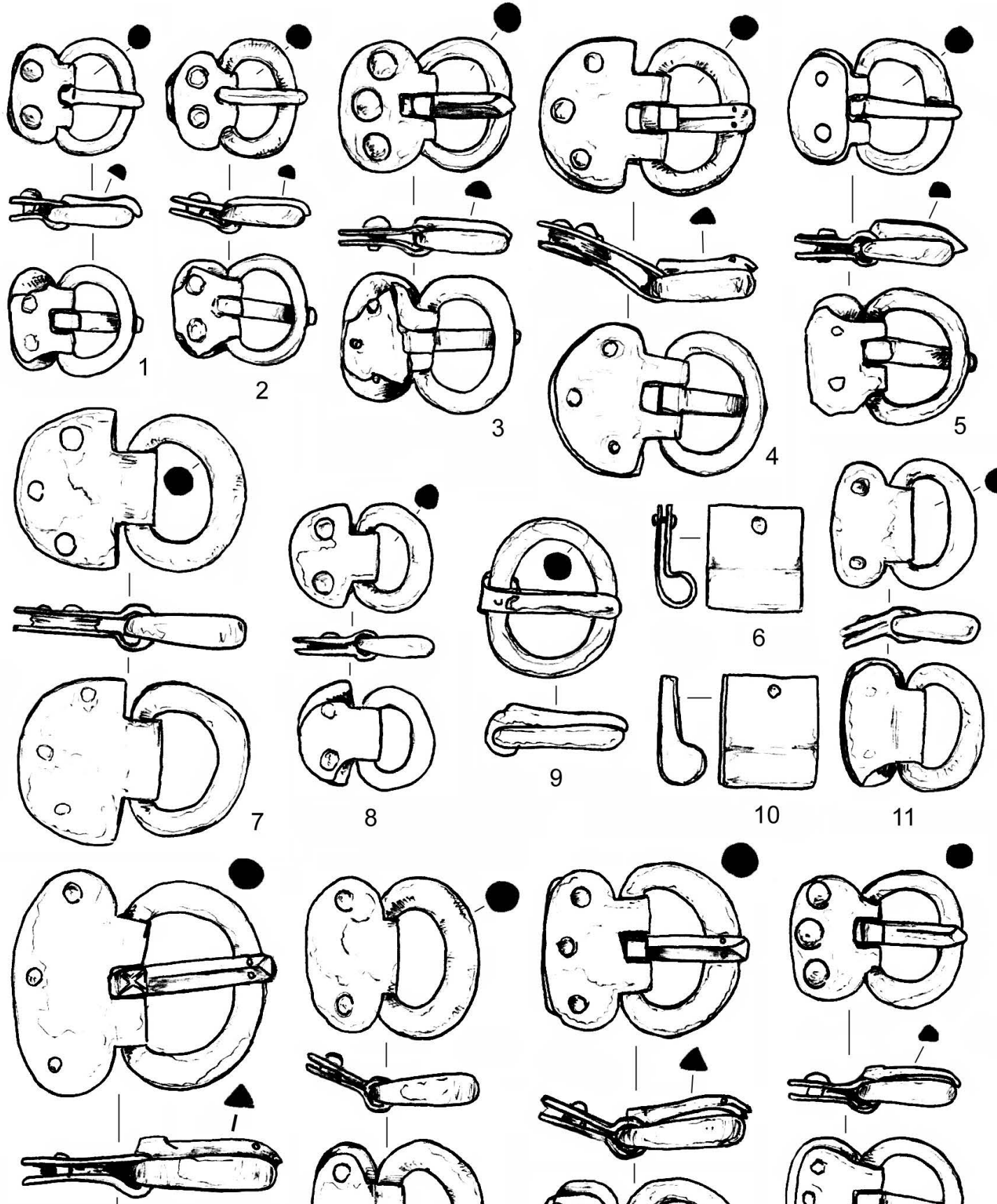

8

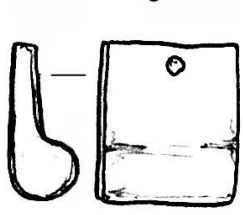

10

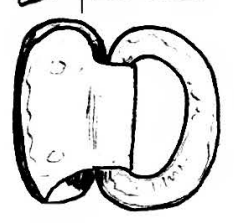

11
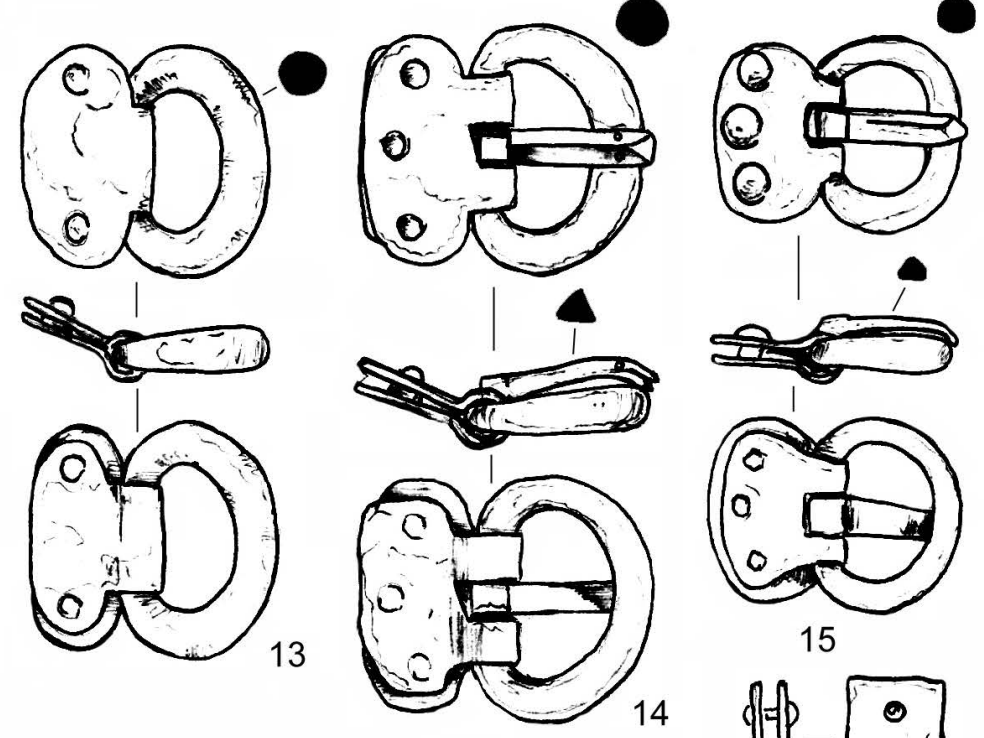

15

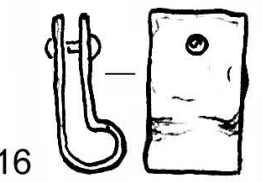

Рис. 8. Могильник Опушки, склеп № 133. Инвентарь погребений в камере:

$1-5,9,12,14,15$ - пряжки; 7, 8, 11, 13 - кольца с зажимами; 6, 10, 16 - обоймы (рисунок С.Б. Шабанова)

Fig. 8. The cemetery of Opushki, burial vault no. 133. Grave goods from the burials in the burial chamber: $1-5,9,12,14,15$ - buckles; 7, 8, 11,13- rings with clamps; 6, 10, 16- clips (drawing: S.B. Shabanov) 


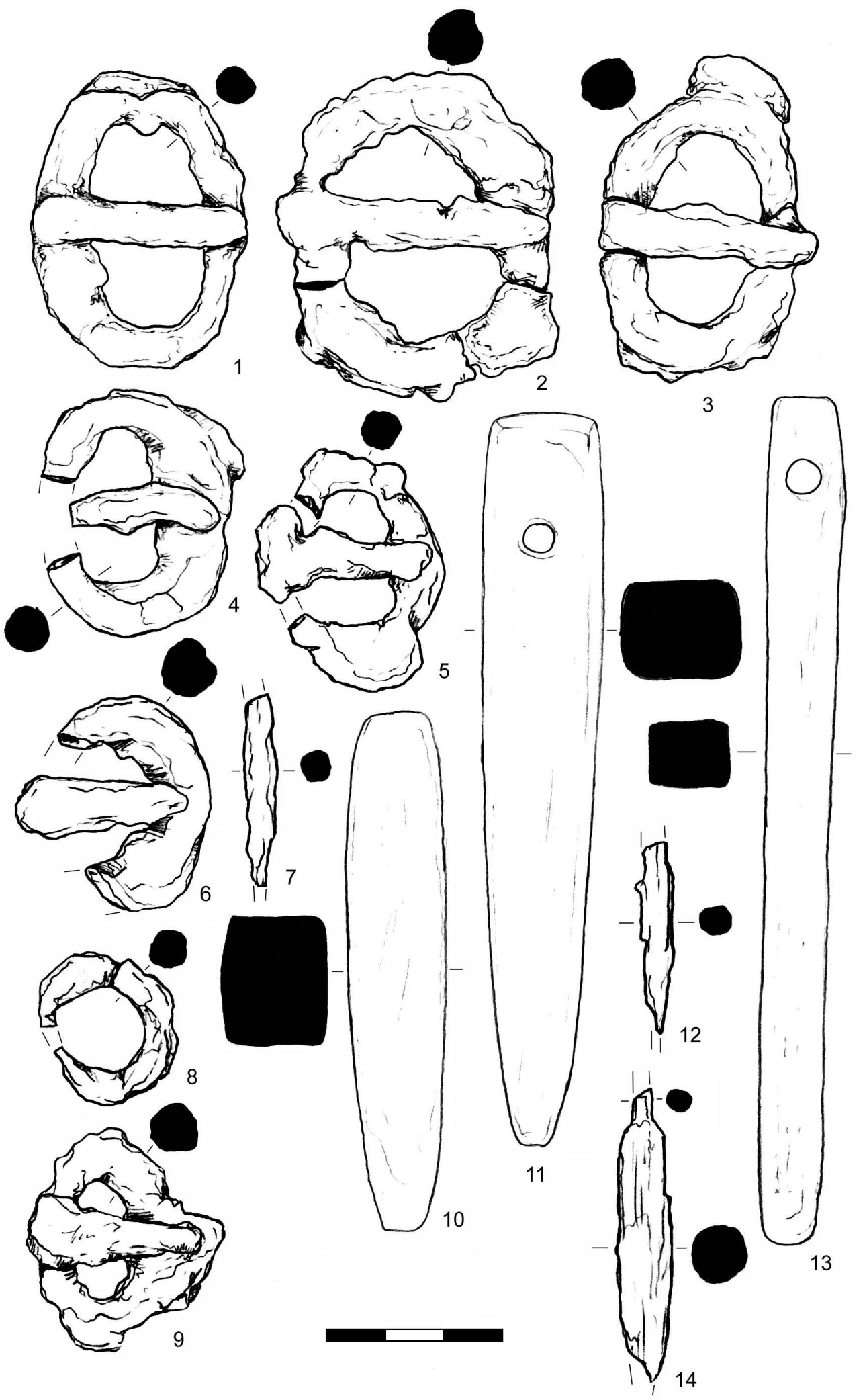

Рис. 9. Могильник Опушки, склеп № 133. Инвентарь погребений в камере:

1-6, 8, 9 - пряжки железные; 7, 12, 14 - предметы железные стержневидные; 10 - камень точильный; $6,11,13$ - оселки каменные (рисунок С.Б. Шабанова)

Fig. 9. The cemetery of Opushki, burial vault no. 133. Grave goods from the burials in the burial chamber:

$1-6,8,9$ - iron buckles; 7, 12, 14 - iron rod-shaped artefacts; 10 - whetstone; $6,11,13-$ stone grindstones (drawing: S.B. Shabanov) 


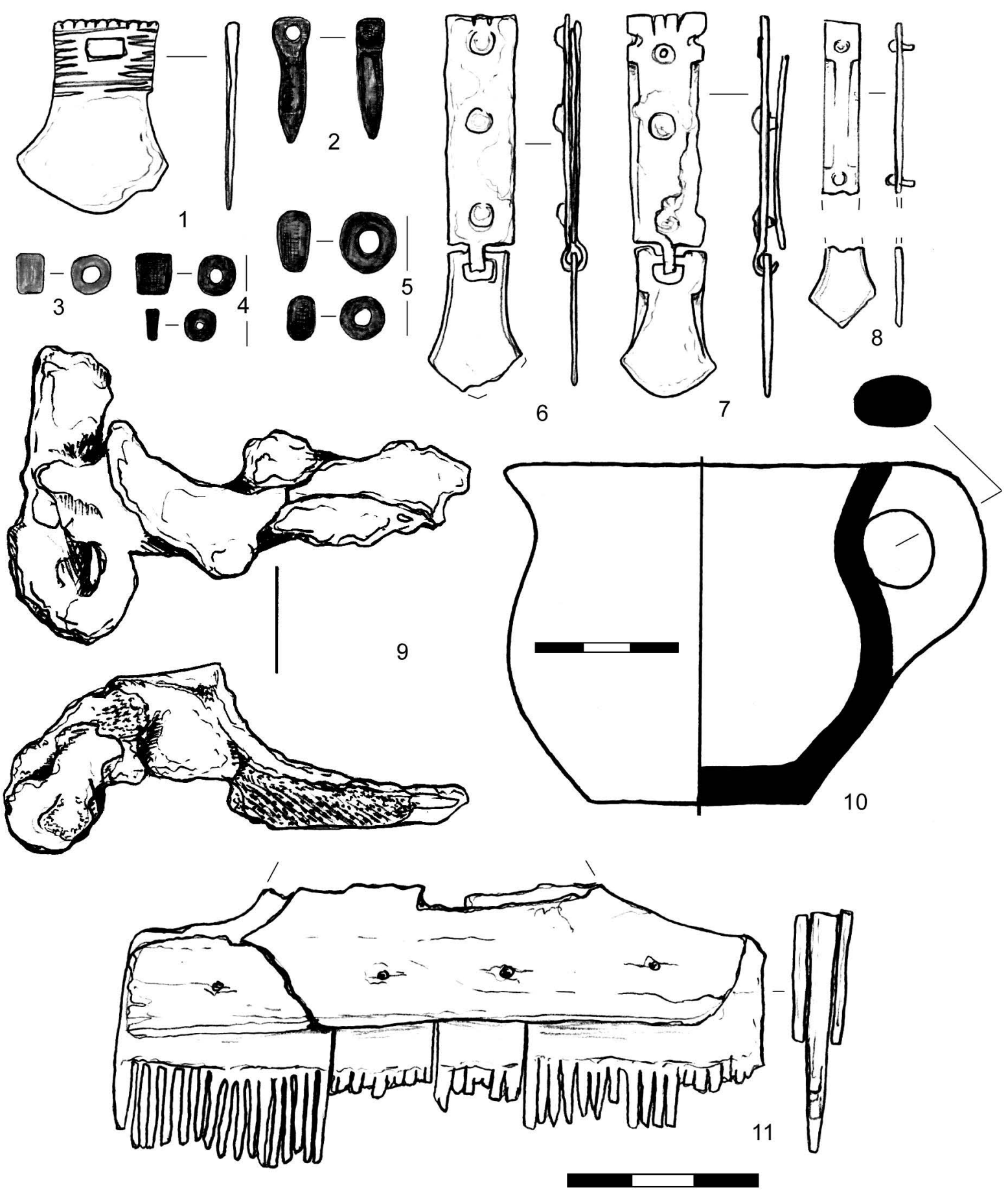

Рис. 10. Могильник Опушки, склеп № 133. Инвентарь погребений в камере:

1 - подвеска серебряная; 2 - подвески гагатовые; 3 - бусина из янтаря; 4, 5 - бусы из гагата; 6, 7 - наконечники ремней; 8 - накладка на ремень и фрагмент наконечника; 9 - фибула железная; 10 - лепной сосуд; 11 - гребень костяной (рисунок С.Б. Шабанова)

Fig. 10. The cemetery of Opushki, burial vault no. 133. Grave goods from the burials in the burial chamber:

1 - silver pendant; 2 - jet pendants; 3 - amber bead; 4, 5 - jet beads;

6, 7 - strap-ends; 8 - belt-fitting and belt-end fragment; 9 - iron brooch;

10 - hand-formed vessel; 11 - bone comb (drawing: S.B. Shabanov) 

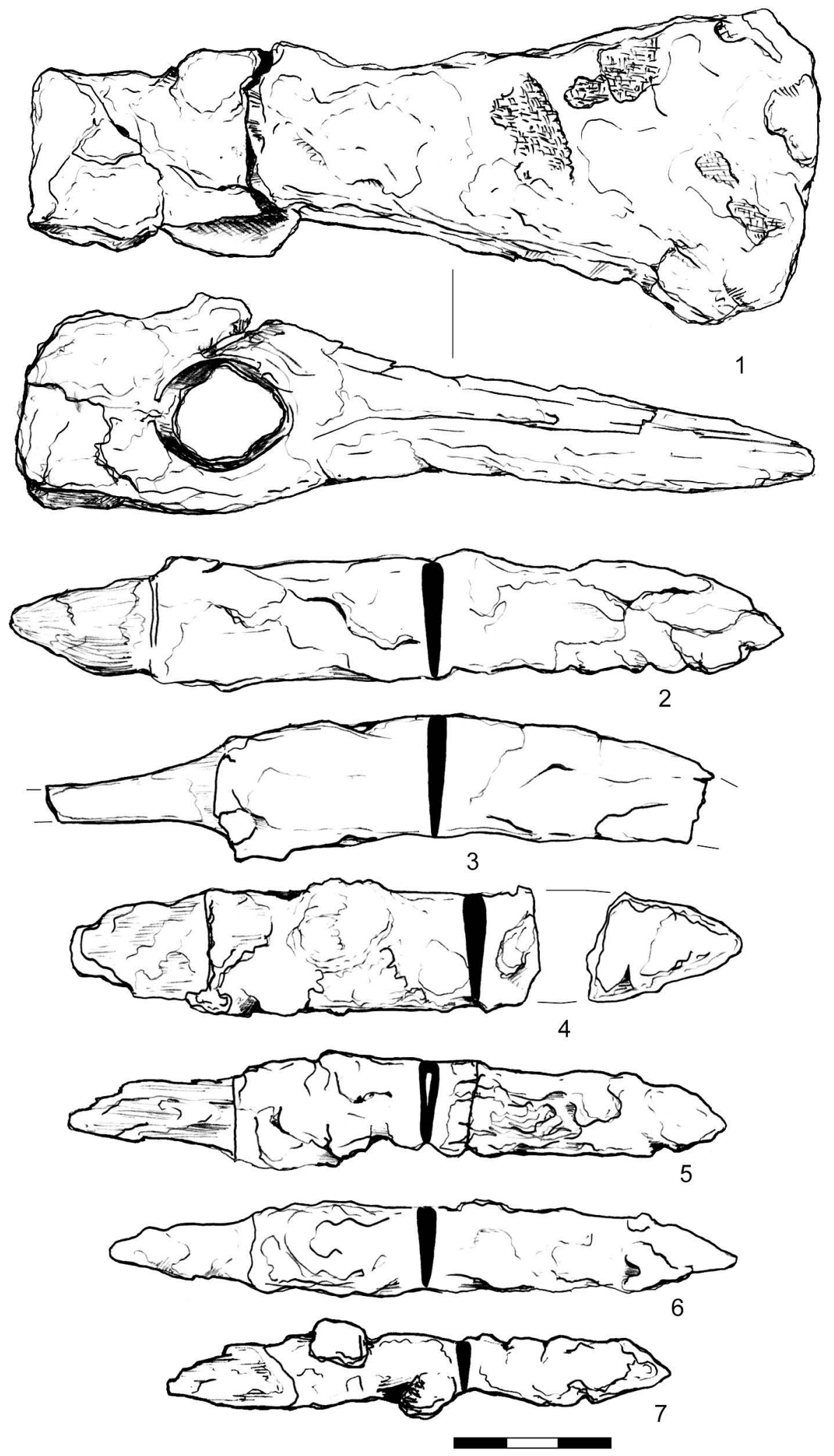

Рис. 11. Могильник Опушки, склеп № 133. Инвентарь погребений в камере:

1 - топор железный; 2-7 - ножи железные (рисунок С.Б. Шабанова)

Fig. 11. The cemetery of Opushki, burial vault no. 133. Grave goods from the burials in the burial chamber: 1 - iron axe; $2-7$ - iron knives (drawing: S.B. Shabanov) 


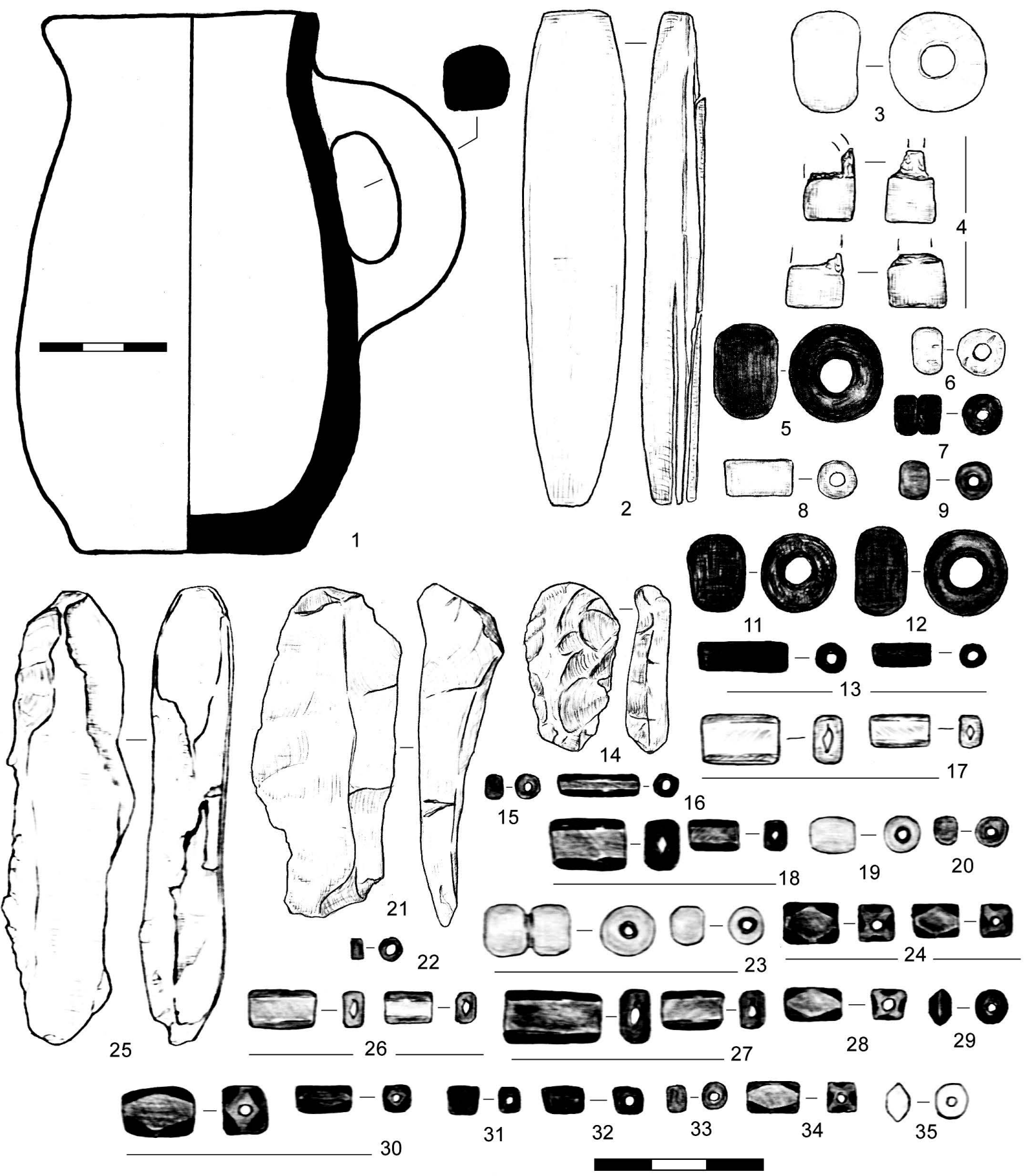

Рис. 12. Могильник Опушки, склеп № 133. Инвентарь погребений в камере:

1 - кувшин лепной; 2 - точильный камень; 3, 5-13, 15-20, 22-24, 26-34 - бусы; 4 - подвески ведерковидные из железа; 14, 21, 25 - отщепы кремневые (рисунок А.А. Стояновой, С.Б. Шабанова)

Fig. 12. The cemetery of Opushki, burial vault no. 133. Grave goods from the burials in the burial chamber: 1 - hand-made pitcher; 2 - grindstone; 3, 5-13, 15-20, 22-24, 26-34 - beads; 4 - iron bucket-shaped pendants; 14, 21, 25 - flint flakes (drawing: A.A. Stoyanova, S.B. Shabanov) 

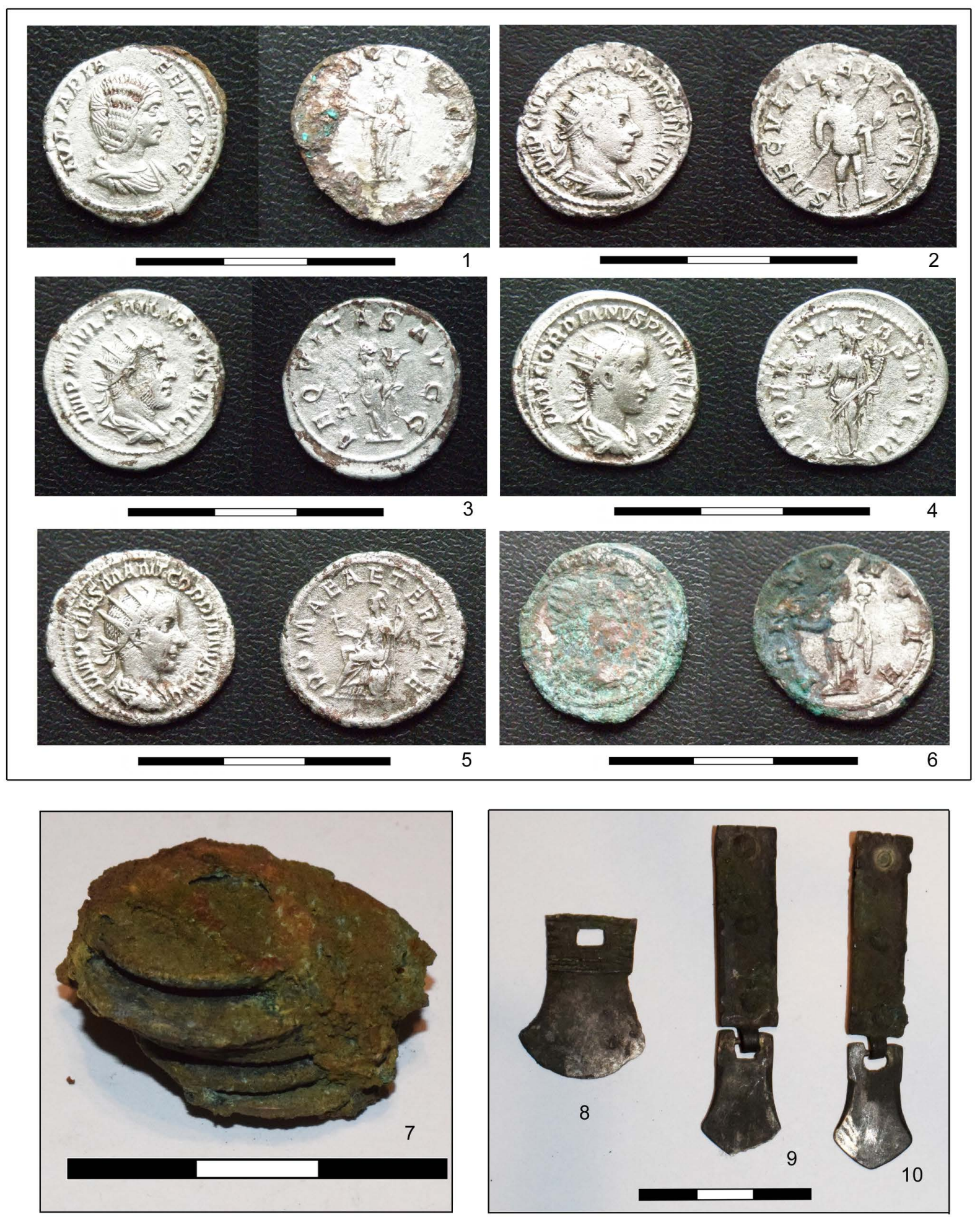

Рис. 13. Могильник Опушки, склеп № 133. Инвентарь погребений в камере:

1-6 - монеты серебряные; 7 - монеты до реставрации; 8-10 - подвеска и наконечники ремней из серебра (фото А.А. Стояновой)

Fig. 13. The cemetery of Opushki, burial vault no. 133. Grave goods from the burials in the burial chamber: 1-6 - silver coins; 7 - coins before the restoration; $8-10$ - silver pendant and strap-ends (photo: A.A. Stoyanova) 

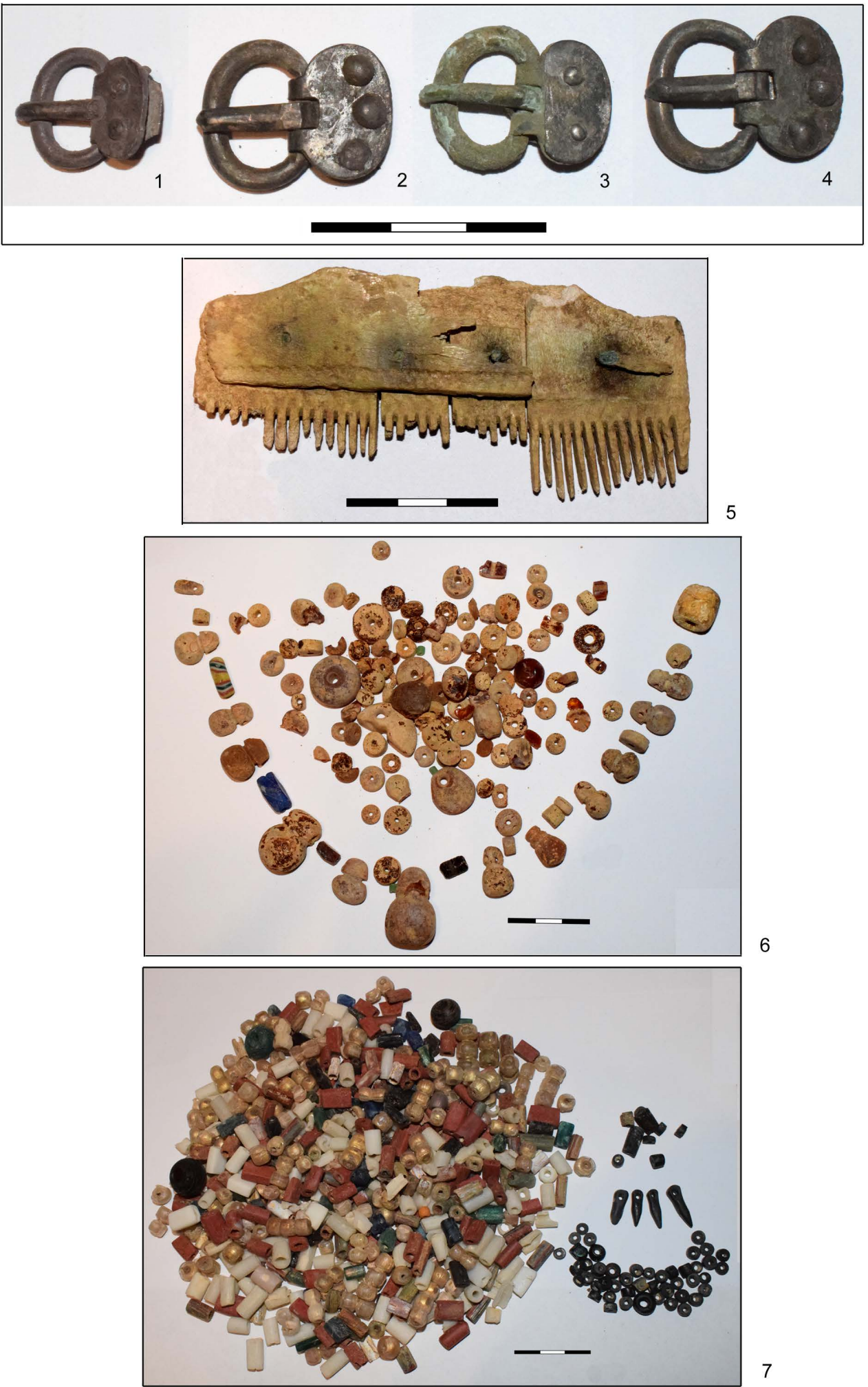

6

Рис. 14. Могильник Опушки, склеп № 133. Погребальный инвентарь:

1-4 - пряжки; 5 - костяной гребень; 6 - набор бус из погребения над сводом;

7 - набор бус из погребения в камере (фото А.А. Стояновой)

Fig. 14. The cemetery of Opushki, burial vault no. 133. Grave goods:

$1-4$ - buckles; 5 - bone comb; 6 - set of beads from the burial above the vaulting;

7 - set of beads from the burial in the burial chamber (photo: A.A. Stoyanova) 


\section{СПИСОК ЛИТЕРАТУРЫ}

Абрамова М. П., 1997. Ранние аланы Северного Кавказа III-V вв. н.э. М. 165 с.

Айбабин А. И., Хайрединова Э. А., 1998. Ранние комплексы могильника у села Лучистое в Крыму // Материалы по археологии, истории и этнографии Таврии. Вып. VI. С. 274-311.

Алексеева Е. М., 1978. Античные бусы Северного Причерноморья. САИ. Вып. Г1-12. М. : Наука. 100 с.

Безуглов С. И., 1988. Позднесарматское погребение знатного воина в степном Подонье // Советская археология. № 4. С. 103-115.

Безуглов С., Захаров А., 1988. Могильник Журавка и финал позднесарматской эпохи в Правобережном Подонье // Известия Ростовского областного музея краеведения. Вып. 3. Ростов н/Д : Рост. кн. изд-во. С. 5-28.

Бруяко И. В., Дзиговский А. Н., Мадыда-Легугко Р., 2017. Studia Baltica et Pontica (Сармато-германский комплекс на городище Картал в низовьях Дуная) // Stratum plus. № 4. С. 233-264.

Васильев А. А., 2010. Удила из княжеского погребения у с. Кишпек, Кабардино-Балкария (балто-черноморские контакты и некоторые вопросы датировки европейских древностей рубежа III-IV вв. н.э.) // Германия - Сарматия. Вып. II. Калининград ; Курск. С. 97-111.

Веймарн Е. В., 1963. Археологічні роботи в районе Інкермана // Археологічні пам’ятки УРСР. Т. ХІІІ. С. 15-89.

Власов В. П., 1999. Лепная керамика из некрополя III-IV вв. н.э. Дружное в Крыму // Сто лет черняховской культуре. Киев. С. 322-371.

Вознесенская Г. А., Левада М. Е.,1999. Кузнечные изделия из могильника Чатырдаг: попытка типологического анализа и технология производства // Сто лет черняховской культуре. Киев. С. 252-276.

Воронов Ю. Н., Шенкао Н. К.,1982. Вооружение воинов Абхазии IV-VII вв. // Древности эпохи Великого переселения народов V-VII веков. М. : Наука. С. 121-165.

Ворошилов А. Н., 2018. Воинское захоронение с плетью из Фанагории // Фанагория. Результаты археологических исследований. Материалы по археологии и истории Фанагории. Т. 7, вып. 4. М. : Ин-т археологии PAH. C. 39-55.

Высотская Т. Н., 1998. Склепы из могильника Совхоз № 10 (Севастопольский): проблемы этноса и хронологии // Материалы по археологии, истории и этнографии Таврии. Вып. VI. С. 256-273.

Габуев Т. А., Малашев В. Ю., 2009. Памятники ранних алан центральных районов Северного Кавказа. М. : Tayc. $468 \mathrm{c}$.

Гопкало О. В., 2008. Бусы и подвески черняховской культуры. Киев. 252 с.

Гудкова А. В., Фокеев М. М., 1984. Земледельцы и кочевники в низовьях Дуная I-IV вв. н.э. Киев : Наукова думка. $118 \mathrm{c}$.

Гущина И. И., Засецкая И. П., 1994. «Золотое кладбище» римской эпохи в Прикубанье. СПб. : Фарн. 172 с.

Демиденко С. В., 2016. Воинское погребение с парадной конской упряжью позднесарматского времени в бассейне реки Курмоярский Аксай // Краткие сообщения Института археологии. Вып. 244. C. $195-221$.

Журавлев Д. В., 2010. Краснолаковая керамика Юго-Западного Крыма І-ІІІ вв. н.э. : (По материалам позднескифских некрополей Бельбекской долины). Симферополь. 320 с.

Зайцев Ю. П., 1997. Охранные исследования в Симферопольском, Белогорском и Бахчисарайском районах // Археологические исследования в Крыму. 1994 год. Симферополь. С. 102-116.

Засецкая И. П., 1993. Материалы Боспорского некрополя второй половины IV - первой половины V в. н.э. // Материалы по археологии, истории и этнографии Таврии. Вып. III. С. 23-105.

Казанский М. М., 1999. Готы на Боспоре Киммерийском // Сто лет черняховской культуре. Киев. С. 277-297.

Контны Б., Савеля Д. Ю., 2006. Вооружение из могильника в Килен-Балке // Материалы по археологии, истории и этнографии Таврии. Вып. ХІІ. Ч. 1. С. 129-160.

Кропоткин В. В., 1978. Черняховская культура и Северное Причерноморье // Проблемы советской археологии. М. : Наука. С. 147-163.

Лобода И. И., 1977. Раскопки могильника Озерное ІІІ в 1963-1965 гг. // Советская археология. № 4. С. 236-252.

Магомедов Б. В., 2001. Черняховская культура. Проблема этноса. Lublin : Wydawnictvo Universitetu Marii Curie-Skladowskiej. $290 \mathrm{c}$. 
Малашев В. Ю., 2000. Периодизация ременных гарнитур позднесарматского времени // Сарматы и их соседи на Дону. Ростов н/Д : Терра : Гефест. С. 194-232.

Мульд С. А., 2016. Погребальные сооружения могильника Нейзац // Крым в сарматскую эпоху. II. 20 лет исследований могильника Нейзац. Симферополь : Наследие тысячелетий. С. 37-75.

Мыц В. Л., Лысенко А. В., Щукин М. Б., Шаров О. В., 2006. Чатыр-Даг - некрополь римской эпохи в Крыму. СПб. : Изд-во СПбИИ РАН : Нестор-История. 208 с.

Пиоро И. С., 1990. Крымская Готия. Киев : Лыбидь. 197 с.

Скрипкин А. С., 1984. Нижнее Поволжье в первые века нашей эры. Саратов : Изд-во Сарат. ун-та. 149 с.

Стоянова А. А., 2004. Бусы и подвески из могильника Нейзац (по материалам раскопок 1996-2001 гг.) // Боспорские исследования. Вып. V. С. 263-319.

Стоянова А. А., 2010. Наборы бус в костюме населения предгорного Крыма во II в. до н.э. - IV в. н.э. // Боспорские исследования. Вып. XXIV. С. 401-410.

Стоянова А. А., 2011. Аксессуары женского костюма II - первой половины III в. н.э. из могильника Нейзац // Исследования могильника Нейзац. Симферополь : Доля. С. 115-151.

Стоянова А. А., 2016. Подвески из могильника Нейзац // Крым в сарматскую эпоху (II в. до н.э. - IV в. н.э.). II. 20 лет исследований могильника Нейзац. Симферополь : Наследие тысячелетий. С. 122-165.

Стржелецкий С. Ф., Высотская Т. Н., Рыжова Л. А., Жесткова Г. И., 2003-2004. Население округи Херсонеса в первой половине I тысячелетия новой эры (по материалам некрополя «Совхоз № 10») // Stratum plus. № 4. С. 27-277.

Трейстер М. Ю., 2011. Об одной группе боспорских золотых перстней II-III вв. н.э. // Боспорские исследования. Вып. XXV. С. 312-322.

Трейстер М. Ю., 2015. Золото Фанагории. Типологический, стилистический и хронологический анализ // Фанагория. Результаты археологических исследований. Т. 2. Золото Фанагории. М. : Ин-т археологии PAH. C. 77-181.

Трейстер М. Ю., 2017. Позднеантичные золотые погребальные пояса // Труды Государственного Эрмитажа. T. 88. C. 310-322.

Труфанов А. А., Колтухов С. Г., 2001-2002. Исследование позднеантичного некрополя у с. Курское в юговосточном Крыму // Stratum plus. № 4. С. 278-295.

Фролова Н. А., Абрамзон М. Г., 2003. Римские монеты в собрании Государственного исторического музея. Каталог. Ч. ІІІ. От Пертинакса до Нумериана. М. : Российская политическая энциклопедия. 341 с.

Хайрединова Э. А., 1995. Бусы из могильника Дружное // Проблемы археологии древнего и средневекового Крыма. Симферополь : Таврия. С. 59-87.

Храпунов И. Н., 2002. Могильник Дружное (III-IV вв. н.э.). Lublin : Wydawnictvo Universitetu Marii CurieSkladowskiej. $313 \mathrm{c}$.

Храпунов И. Н., 2006. Склеп III в. н.э. из могильника Нейзац // Проблемы истории, филологии, культуры. Вып. XVI/1. С. 104-118.

Храпунов И. Н., 2008а. Склеп IV в. н.э. из могильника Нейзац // Проблемы истории, филологии, культуры. Вып. ХXI. С. 356-392.

Храпунов И. Н., 2008б. Наконечники ремней из могильника Нейзац // Материалы по археологии, истории и этнографии Таврии. Вып. XIV. С. 61-79.

Храпунов И. Н., 2010. Оружие из могильника Нейзац // Terra Barbarica. Lodz; Warsawa. S. 535-555.

Храпунов И. Н., 2011а. Склеп с погребениями III-IV вв. н.э. из могильника Нейзац. Симферополь : Доля. 72 с.

Храпунов И. Н., 2011б. Некоторые итоги исследований могильника Нейзац // Исследования могильника Нейзац. Симферополь : Доля. С. 13-113.

Храпунов И. Н., 2016. Серебряные и бронзовые пряжки из могильника Нейзац // Крым в сарматскую эпоху. II. 20 лет исследований могильника Нейзац. Симферополь : Наследие тысячелетий. С. 97-121.

Храпунов И. Н., 2018а. Склеп с вещами в догуннском полихромном стиле из могильника Опушки // Крым в сарматскую эпоху (II в. до н.э. - IV в. н.э.). III. Симферополь : ИП Бровко А.А. С. 137-169.

Храпунов И. Н., 2018б. Склепы с короткими дромосами в Крыму и на Северном Кавказе // Крым в сарматскую эпоху (II в. до н.э. - IV в. н.э.). IV. Симферополь : ИП Бровко А.А. С. 133-145. 
Храпунов И. Н., 2019. Археологическая культура позднеримского времени в предгорном Крыму // Российская археология. № 1. С. 32-49.

Храпунов И. Н., Стоянова А. А., 2018. Украшения в позднеримском полихромном стиле из могильника Опушки в Крыму // Stratum plus. № 4. С. 255-262.

Храпунов Н. И., 2009. Монеты из могильника Нейзац (находки 1996-2008 гг.) // Проблемы истории, филологии, культуры. Вып. 3 (25). С. 55-82.

Шаров О. В., 2007. Керамический комплекс некрополя Чатыр-Даг: хронология комплексов с римскими импортами. СПб. : Нестор-История. 208 с.

Beilke-Voigt I., 1998. Frühgeschichtliche Miniaturobjekte mit Amulettcharakter zwischen Britischen Inseln und Schwarzem Meer. Bonn : Verlag Dr. Rudolf Habelt GMBH. 342 S.

Kazanski M., 1994. Les éperons, les umbo, les manipules de boucliers et les haches de l'époque romaine tardive dans la région pontique: origine et diffusion // Beiträge zu römischer und barbarischer Bewaffnung in den ersten vier nachchristlichen Jahrhunderten. Lublin ; Marburg : Vorgeschichtliches Seminar der PhillippsUniversität Marburg. S. 429-484.

Kazanski M., 2011. Kishpek, Ekazhevo and Varpelev: on the problem of Pontic-Scandinavian relations in the Late Roman Period // Inter Ambo Maria. Contacts between Scandinavia and the Crimea in the Roman Period. Kristiansad ; Simferopol : Dolya Publishing House. P. 91-101.

Mączyńska M., Gercen A., Ivanova O., Černyš S., Lukin S., Urbaniak A., Bemmann J., Schneider K., Jakubczyk I., 2016. Das Frühmittelalterliche Gräberfeld Almalyk-Dere am Fusse des Mangup auf der Südwestkrim. Mainz : Verlag des Römisch-Germanischen Zentralmusums. $205 \mathrm{~S}$.

Mączyński P., Polit B., 2016a. Fire Striking Tools from the Neyzats and Druzhnoe Cemeteries // Крым в сарматскую эпоху. II. 20 лет исследований могильника Нейзац. Симферополь : Наследие тысячелетий. С. 76-96.

Mączyński P., Polit B., 2016b. Wytwory krzemienne z cmentarzyska z poźnej staroźytności Nejzac na Krymie // Wiadomości Archeologiczne. T. LXVII. S. 175-193.

Mattingly H., Sydanham E. A., 1936. The Roman Imperial Coinage. Vol. IV. Pt. I : Pertinax to Geta. London : Spink \& Son. 406 p.

Mattingly H., Sydanham E. A., Sutherland C. H. V., 1949. The Roman Imperial Coinage. Vol. IV. Pt. III : Gordian III Uranius Antonius. London : Spink \& Son. 246 p.

Thomas S., 1960. Studien zu den Germanischen Kämmen der Römischen Kaiserzeit // Arbeits- und Forschungsberichte zur Sächsischen Bodendenkmalpflege. Bd. 8. S. 54-215.

\section{REFERENCES}

Abramova M.P., 1997. Rannie alany Severnogo Kavkaza III-Vvv. n.e. [The Early Alans of the North Caucasus $3^{\text {rd }}$ $5^{\text {th }}$ Centures AD]. Moscow. $165 \mathrm{p}$.

Aibabin A.I., Khairedinova E.A., 1998. Rannie kompleksy mogilnika u sela Luchistoe v Krymu [Early Complexes of the Cemetery Near the Village of Luchistoe in Crimea]. Materialy po arkheologii, istorii i etnografii Tavrii [Materials in Archeology, History and Etnography of Tauria], vol. VI, pp. 274-311.

Alekseeva E.M., 1978. Antichnye busy Severnogo Prichernomorya [Ancient Beads in the Northern Black Sea Area]. Svod Arkheologicheskih Istochnikov, iss. Г1-12. Moscow, Nauka Publ. 100 p.

Bezuglov S.I., 1988. Pozdnesarmatskoe pogrebenie znatnogo voina v stepnom Podonye [A Late Sarmatian Burial of a Noble Warrior in the Steppe Belt of the Don Basin]. Sovetskaya arkheologiya [Soviet Archaeology], no. 4, pp. 103-115.

Bezuglov S., Zakharov A., 1988. Mogilnik Zhuravka i final pozdnesarmatskoy epokhi v Pravoberezhnom Podonye [The Cemetery Zhuravka and the Final of the Late Sarmatian Period on the Right-Bank Don Area]. Izvestiya Rostovskogo oblastnogo muzeya kraevedeniya [Proceedings of the Rostov Regional Museum], vol. 3. Rostov-na-Donu, Rostov. kn. izd-vo, pp. 5-28.

Bruyako I.V., Dzigovskiy A.N., Madyda-Legutko R., 2017. Studia Baltica et Pontica (Sarmato-germanskiy kompleks na gorodishche Kartal v nizovyakh Dunaya) [Studia Baltica et Pontica (Sarmatian-Germanic Complex at the Kartal Hillfort on the Lower Danube]. Stratum plus, no. 4, pp. 233-264. 
Vasilyev A.A., 2010. Udila iz knyazheskogo pogrebeniya u s. Kishpek, Kabardino-Balkariya (balto-chernomorskie kontakty i nekotorye voprosy datirovki evropeyskikh drevnostey rubezha III-IV vv. n.e.) [Horse Bits from a Princely Grave Near the Village of Kishpek in Kabardino-Balkaria (the Baltic Sea - Black Sea Contacts and Some Aspects of the Chronology of European Antiquities from ca. 300 AD)]. Germania - Sarmatia, iss. II. Kaliningrad; Kursk, pp. 97-111.

Veymarn E.V., 1963. Arkheologichni roboty v rayone Inkermana [Archaeological Works in the Area of Inkerman]. Arkheologichni pamyatky URSR [Archaeological Sites of the USSR], vol. XIII, pp. 15-89.

Vlasov V.P., 1999. Lepnaya keramika iz nekropolya III-IV vv. n.e. Druzhnoe v Krymu [Hand-Formed Pottery from the Third-to-Fourth-Century AD Cemetery of Druzhnoe in the Crimea]. Sto let chernyakhovskoy culture [The Centenary of the Cherniakhov Culture]. Kiev, pp. 322-371.

Voznesenskaya G.A., Levada M.E., 1999. Kuznechnye izdeliya iz mogilnika Chatyrdag: popytka tipologicheskogo analiza I tekhnologiya proizvodstva [The Forged Ware from the Cemetery of Chatyrdag: An Attempt of Typological Analysis and the Production Technique]. Sto let chernyakhovskoy culture [The Centenary of the Cherniakhov Culture]. Kiev, pp. 252-276.

Voronow Yu.N., Shenkao N.K., 1982. Vooruzhenie voinov Abkhazii IV-VII vv. [The Weaponry of Abkhazian Warriors from the Fourth to Seventh Century]. Drevnosti epokhi Velikogo pereseleniya narodov VVII vekov [The Antiquities from the Great Migration Period, the Fifth to Seventh Century]. Moscow, Nauka Publ., pp. 121-165.

Voroshilov A.N., 2018. Voinskoe zakhoronenie s pletyu iz Fanagorii [A Warrior's Grave with a Whip from Fanagoria]. Fanagoriya. Rezultaty arkheologicheskikh issledovaniy. Materialy po arkheologii i istorii Fanagorii [Phanagoria: the Results of the Archaeological Researches. Materials in Archaeology and History of Phanagoria], vol. 7, iss. 4. Moscow, Institute of archaeology RAS, pp. 39-55.

Vysotskaya T.N., 1998. Sklepy iz mogilnika Sovkhoz № 10 (Sevastopolskiy): problem etnosa i khronologii [Vaults of Sovkhoz 10 (Sevastopolskiy) Cemetery: Problems of Ethnos and Chronology]. Materialy po arkheologii, istorii i etnografii Tavrii [Materials in Archeology, History and Etnography of Tauria], vol. VI, pp. 256-273.

Gabuev T.A., Malashev V.Yu., 2009. Pamyatniki rannikh alan tsentralnykh rayonov Severnogo Kavkaza [The Early Alanic Sites in the Central Areas of the North Caucasus]. Moscow, Taus Publ. 468 p.

Gopkalo O.V., 2008. Busy i podveski chernyakhovskoy kultury [The Beads and Pendants of the Cherniakhov Culture]. Kiev. 252 p.

Gudkova A.V., Fokeev M.M., 1984. Zemledeltsy i kochevniki v nizovyakh Dunaya I-IV vv. n.e. [The Farmers and Nomads in the Lower Danube Area from the First to Fourth Century AD]. Kiev, Naukova dumka. 118 p.

Gushchina I.I., Zasetskaya I.P., 1994. "Zolotoe kladbishche» rimskoy epokhi v Prikubanye [“Gold Cemetery” of the Roman Time in the Kuban Region]. Saint Petersburg, Farn Publ. 172 p.

Demidenko S.V., 2016. Voinskoe pogrebenie s paradnoy konskoy upryazhyu pozdnesarmatskogo vremeni v basseine reki Kurmoyarskiy Aksay [A Warrior's Grave with Ceremonial Horse Trappings of the Late Sarmatian Period in the Kurmoyarsky Aksay River Basin]. Kratkie soobshcheniya Instituta arkheologii [BriefCommunications of the Institute of Archaeology], iss. 244, pp. 195-221.

Zhuravlev D.V., 2010.Krasnolakovaya keramika Yugo-Zapadnogo Kryma I-III vv. n.e.: (Po materialam pozdneskifskikh nekropoley Belbekskoy doliny) [Terra Sigillata of the South-Western Crimea in the $1^{\text {st }}-$ $3^{\text {rd }}$ Centures A.D. (Finds from Late Scythian Necropolis of the Belbek-River Valley]. Simferopol. 320 p.

Zaytsev Yu.P., 1997. Okhrannye issledovaniya v Simferopolskom, Belogorskom i Bakhchisarayskom rayonakh [Rescue Archaeology in Simferopol, Belogorsk and Bakhchisaray Districts]. Arkheologicheskie issledovaniya v Krymu. 1994 god [Archaeological Researches in Crimea. 1994]. Simferopol, pp. 102-116.

Zasetskaya I.P., 1993. Materialy Bosporskogo nekropolya vtoroy poloviny IV - pervoy poloviny V v. n.e. [Materials from Bosporus Necropolis of the Second Half of the $4^{\text {th }}$ the First Half of the $5^{\text {th }}$ Centuries AD]. Materialy po arkheologii, istorii i etnografii Tavrii [Materials in Archaeology, History and Etnography of Tauria], iss. III, pp. 23-105.

Kazanskiy M.M., 1999. Goty na Bospore Kimmeriyskom [The Goths at the Cimmerian Bosporus]. Sto let chernyakhovskoy culture [The Centenary of the Cherniakhov Culture]. Kiev, pp. 277-297.

Kontny B., Savelya D.Yu., 2006. Vooruzhenie iz mogilnika v Kilen-Balke [Weaponry from Kilen-BalrfCemetery]. Materialy po arkheologii, istorii i etnografii Tavrii [Materials in Archeology, History and Etnography of Tauria], iss. XII, part 1, pp. 129-160. 
Kropotkin V.V., 1978. Chernyakhovskaya kultura i Severnoe Prichernomor'e [The Cherniakhov Culture and the Northern Black Sea Area]. Problemy sovetskoy arkheologii [The Problems of the Soviet Archaeology]. Moscow, Nauka Publ., pp. 147-163.

Loboda I. I., 1977. Raskopki mogilnika Ozernoe III v 1963-1965 gg. [The Excavations of the Cemetery of Ozernoe III in 1963-1965]. Sovetskaya arkheologiya [Soviet Archaeology], no. 4, pp. 236-252.

Magomedov B.V., 2001. Chernyakhovskaya kultura. Problema etnosa [The Cherniakhov Culture: the Problem of the Ethnos]. Lublin, Wydawnictvo Universitetu Marii Curie-Skladowskiej. 290 p.

Malashev V.Yu., 2000. Periodizatsiya remennykh garnitur pozdnesarmatskogo vremeni [The Periodization of Belt Sets of the Late Sarmatian Era]. Sarmaty i ikh sosedi na Donu [The Sarmatians and Their Neighbors on the Don]. Rostov-na-Donu, Terra Publ.; Gefest Publ., pp. 194-232.

Muld S.A., 2016. Pogrebalnye sooruzheniya mogilnika Neyzats [Burial Structures of the Cemetery of Neyzats]. Krym v sarmatskuyu epokhu. II. 20 let issledovaniy mogilnika Neyzats [The Crimea in the Age of the Sarmatians (200 BC AD 400). II. 20 Years of Researches at the Cemetery of Neyzats]. Simferopol, Nasledie tysyacheletiy Publ., pp. 37-75.

Myts V.L., Lysenko A.V., Shchukin M.B., Sharov O.V., 2006. Chatyr-Dag-nekropol rimskoy epokhi v Krymu [ChatyrDag: A Necropolis of Roman Period in the Crimea]. Saint Petersburg, SPbIH RAS, Nestor-Istoriya Publ. 208 p.

Pioro I.S., 1990. Krymskaya Gotiya [Crimean Gothia]. Kiev, Lybyd’ Publ. 197 p.

Skripkin A.S., 1984. Nizhnee Povolzhe v pervye veka nashey ery [The Lower Volga Area in the First Centuries AD]. Saratov, SSU. 149 p.

Stoyanova A.A., 2004. Busy i podveski iz mogilnika Neyzats (po materialam raskopok 1996-2001 gg.) [Beads and Pendants from the Cemetery of Neyzats (of the Materials of Excavations in 1996-2001]. Bosporskie issledovaniya [Bosporos Studies], iss. V, pp. 263-319.

Stoyanova A.A., 2010. Nabory bus v kostume naseleniya predgornogo Kryma vo II v. do n.e. - IV v. n.e. [Sets of Beads in the Costumes of the Population on the Piedmont of the Crimea in the $2^{\text {nd }}$ Century BC $4{ }^{\text {th }}$ Century AD]. Bosporskie issledovaniya [Bosporos Studies], iss. XXIV, pp. 401-410.

Stoyanova A.A., 2011. Aksessuary zhenskogo kostyuma II - pervoy poloviny III v. n.e. iz mogilnika Neyzats [The Second and the First Half of the Third Century AD Female Costume Accessories from the Cemetery of Neyzats]. Issledovaniya mogilnika Neyzats [Exploring the Cemetery of Neyzats]. Simferopol, Dolya Publ., pp. 115-151.

Stoyanova A.A., 2016. Podveski iz mogilnika Neyzats [Pendants from the Cemetery of Neyzats]. Krym v sarmatskuyu epokhu (II v. do n.e. -IV v. n.e.). II. 20 let issledovaniy mogilnika Neyzats [The Crimea in the Age of the Sarmatians (200 BC AD 400). II. 20 Years of Researches at the Cemetery of Neyzats]. Simferopol, Nasledie tysyacheletiy Publ., pp. 122-165.

Strzheletskiy S.F., Vysotskaya T.N., Ryzhova L.A., Zhestkova G.I., 2003-2004. Naselenie okrugi Khersonesa v pervoy polovine I tysyacheletiya novoy ery (po materialam nekropolya «Sovkhoz № 10» [The Population in the Neighborhood of Chersonesos Tauricus in the First Half of $1^{\text {st }}$ Millenium A. D. (By Materials of the Necropolis “Sovkhoz No. 10”)]. Stratum plus, no. 4, pp. 27-277.

Treister M.Yu., 2011. Ob odnoy gruppe bosporskikh zolotykh perstney II-III vv. n.e. [About One Group of the Bosporus Gold Finger Rings of the $2^{\text {nd }}-3^{\text {rd }}$ Centuries AD]. Bosporskie issledovaniya [Bosporos Studies], iss. XXV, pp. 312-322.

Treister M.Yu., 2015. Zoloto Fanagorii. Tipologicheskiy, stilisticheskiy I khronologicheskiy analiz [The Gold of Phanagoria: Its Typological, Stylistic, and Chronological Analysis]. Fanagoriya. Rezultaty arkheologicheskikh issledovaniy. T. 2. Zoloto Fanagorii [Phanagoria. The Results of the Archaeological Researches. Vol. 2. The Gold of Phanagoria]. Moscow, Institute of Archaeology RAS, pp. 77-181.

Treister M.Yu., 2017. Pozdneantichnye zolotye pogrebalnye poyasa [Late Antique Funeral Belts from the Bosporus]. Trudy Gosudarstvennogo Ermitazha [Proceedings of the State Hermitage Muzeum], vol. 88, pp. 310-322.

Trufanov A.A., Koltukhov S.G., 2001-2002. Issledonanie pozdneantichnogo nekropolya u s. Kurskoe v yugovostochnom Krymu [A Study of the Late Antique Necropolis at the Village Kurskoe in the South-Eastern Crimea]. Stratum plus, no. 4, pp. 278-295.

Frolova N.A., Abramzon M.G., 2003. Rimskie monety v sobranii Gosudarstvennogo istoricheskogo muzeya. Katalog. Part III. Ot Pertinaksa do Numeriana [The Roman Coins in the State Historical Museum Collection. Catalogue. Part 3: From Pertinax to Numerian]. Moscow, Rossiyskaya politicheskaya entsiklopedia Publ. 341 p. 
Khayredinova E.A., 1995. Busy iz mogilnika Druzhnoe [The Beads from the Cemetery of Druzhnoe]. Problemy arkheologii drevnego i srednevekovogo Kryma [The Problems of Archaeology of the Ancient and Mediaeval Crimea]. Simferopol, Tavriya Publ., pp. 59-87.

Khrapunov I.N., 2002. Mogilnik Druzhnoe (III-IV vv. n.e.) [The Cemetery of Druzhnoe]. Lublin, Wydawnictvo Universitetu Marii Curie-Skladowskiej. 313 p.

Khrapunov I.N., 2006. Sklep III v. n.e. iz mogilnika Neyzats [A Vault $3^{\text {rd }}$ Century A. D. in the Cemetery of Neyzats]. Problemy istorii, filologii, kultury [Journal of Historical, Philological and Cultural Studies], iss. XVI/1, pp. 104-118.

Khrapunov I.N., 2008a. Sklep IV v. n.e. iz mogilnika Neyzats [A Vault $4^{\text {th }}$ Century A. D. in the Cemetery of Neyzats]. Problemy istorii, filologii, kultury [Journal of Historical, Philological and Cultural Studies], iss. XXI, pp. 356-392.

Khrapunov I.N., 2008b. Nakonechniki remney iz mogilnika Neyzats [Strap-Ends from the Cemetery of Neyzats]. Materialy po arkheologii, istorii i etnografii Tavrii [Materials in Archeology, History and Etnography of Tauria], iss. XIV, pp. 61-79.

Khrapunov I.N., 2010. Oruzhie iz mogilnika Neyzats [Weaponry from the Cemetery of Neyzats]. Terra Barbarica. Lodz, Warsawa, s. 535-555.

Khrapunov I.N., 2011a. Sklep s pogrebeniyami III-IVvv. n.e. iz mogilnika Neyzats [A Vault with the Third and Fourth Century AD Burials in the Cemetery of Neyzats]. Simferopol, Dolya Publ. 72 p.

Khrapunov I.N., 2011b. Nekotorye itogi issledovaniy mogilnika Neyzats [Some Results of the Researches of the Cemetery of Neyzats]. Issledovaniya mogilnika Neyzats [Exploring the Cemetery of Neyzats]. Simferopol, Dolya Publ., pp. 13-113.

Khrapunov I.N., 2016. Serebryanye i bronzovye pryazhki iz mogilnika Neyzats [Silver and Bronze Buckles from the Cemetery of Neyzats]. Krym v sarmatskuyu epokhu. II. 20 let issledovaniy mogilnika Neyzats [The Crimea in the Age of the Sarmatians (200 BC AD 400). II. 20 Years of Researches at the Cemetery of Neyzats]. Simferopol, Nasledie tysyacheletiy Publ., pp. 97-121.

Khrapunov I.N., 2018a. Sklep s veshchavi v dogunnskom polikhromnom stile iz mogilnika Opushki [A Burial Vault with Goods in the Pre-Hunnic Polychrom Style in Opushki Cemetery]. Krym v sarmatskuyu epokhu (II v. do n.e. $I V$ v. n.e.). III [The Crimea in the Age of the Sarmatians (200 BC AD 400). III]. Simferopol, IP Brovko A.A. Publ., pp. 137-169.

Khrapunov I.N., 2018b. Sklepy s korotkimi dromosami v Krymu i na Severnom Kavkaze [Burial Short-Corridor Vaults in the Crimea and in the North Caucasus]. Krym v sarmatskuyu epokhu (II v. do n.e. - IV v. n.e.). IV [The Crimea in the Age of the Sarmatians (200 BC AD 400). IV]. Simferopol, IP Brovko A.A. Publ., pp. 133-145.

Khrapunov I.N., 2019. Arkheologicheskaya kultura pozdnerimskogo vremeni v predgornom Krymu [Archaeological Culture of the Late Roman Period in the Piedmont Crimea]. Rossiyskaya arkheologiya [Russian Archaeology], no. 1, pp. 32-49.

Khrapunov I.N., Stoyanova A.A., 2018. Ukrasheniya v pozdnerimskom polikhromnom stile iz mogilnika Opushki v Krymu [Adornments of the Late Roman Polychrome Style in the Ctmetery of Opushki in the Crimea]. Stratum plus, no. 4, pp. 255-262.

Khrapunov N.I., 2009. Monety iz mogilnika Neyzats (nakhodki 1996-2008 gg.) [Coins from the Necropolis of Neyzats (1996-2008)]. Problemy istorii, filologii, kultury [Journal of Historical, Philological and Cultural Studies], iss. 3 (25), pp. 55-82.

Sharov O.V., 2007. Keramicheskiy kompleks nekropolya Chatyr-Dag: khronologiya kompleksov s rimskimi importami [The Pottery Complex of the Cemetery of Chatyr-Dag: A Chronology of Assemblages with Roman Imports]. Saint Petersburg, Nestor-Istoriya Publ. 208 p.

Beilke-Voigt I., 1998. Frühgeschichtliche Miniaturobjekte mit Amulettcharakter zwischen Britischen Inseln und Schwarzem Meer. Bonn, Verlag Dr. Rudolf Habelt GMBH. 342 p.

Kazanski M., 1994. Les éperons, les umbo, les manipules de boucliers et les haches de l'epoque romaine tardive dans la région pontique: origine et diffusion. Beiträge zu römischer und barbarischer Bewaffnung in den ersten vier nachchristlichen Jahrhunderten. Lublin, Marburg, Vorgeschichtliches Seminar der PhillippsUniversität Marburg, pp. 429-484.

Kazanski M., 2011. Kishpek, Ekazhevo and Varpelev: on the Problem of Pontic-Scandinavian Relations in the Late Roman Period. Inter Ambo Maria. Contacts between Scandinavia and the Crimea in the Roman Period. Kristiansad; Simferopol, Dolya Publishing House, pp. 91-101. 
Mączyńska M., Gercen A., Ivanova O., Černyš S., Lukin S., Urbaniak A., Bemmann J., Schneider K., Jakubczyk I., 2016. Das Frühmittelalterliche Gräberfeld Almalyk-Dere am Fusse des Mangup auf der Südwestkrim. Mainz, Verlag des Rőmisch-Germanischen Zentralmusums. 205 p.

Mączyński P., Polit B., 2016a. Fire Striking Tools from the Neyzats and Druzhnoe Cemeteries. Krym v sarmatskuyu epokhu. II. 20 let issledovaniy mogilnika Neyzats [The Crimea in the Age of the Sarmatians (200 BC AD 400). II. 20 Years of Researches at the Cemetery of Neyzats]. Simferopol, Nasledie tysyacheletiy Publ., pp. 76-96.

Mączyński P., Polit B., 2016b. Wytwory krzemienne z cmentarzyska z poźnej staroźytności Nejzac na Krymie. Wiadomości Archeologiczne, vol. LXVII, pp. 175-193.

Mattingly H., Sydanham E.A., 1936. The Roman Imperial Coinage. Vol. IV. Pt. I: Pertinax to Geta. London, Spink \& Son. $406 \mathrm{p}$.

Mattingly H., Sydanham E.A., Sutherland C.H.V., 1949. The Roman Imperial Coinage. Vol. IV. Pt. III: Gordian III Uranius Antonius. London, Spink \& Son. 246 p.

Thomas S., 1960. Studien zu den Germanischen Kämmen der Römischen Kaiserzeit. Arbeits- und Forschungsberichte zur Sächsischen Bodendenkmalpflege, vol. 8, pp. 54-215.

\section{Information About the Author}

Igor N. Khrapunov, Doctor of Science (History), Professor, Department of Ancient and Medieval History, Taurida Academy, V.I. Vernadsky Crimean Federal University, Akademika Vernadskogo Avenue, 4, 295007 Simferopol, Russian Federation, igorkhrapunov@mail.ru, https://orcid.org/0000-0002-3961-6297

\section{Информация об авторе}

Игорь Николаевич Храпунов, доктор исторических наук, профессор кафедры истории древнего мира и средних веков, Таврическая академия Крымского федерального университета им. В.И. Вернадского, просп. Академика Вернадского, 4, 295007 г. Симферополь, Российская Федерация, igorkhrapunov@mail.ru, https://orcid.org/0000-0002-3961-6297 